MUSICA THEORICA 2020, V. 5.2

SCIENTIFIC ARTICLE

Data do recebimento: 01/06/2021

Data da aprovação final: 25/07/2021

\title{
Deciphering Flavio Pereira's Reading of Dostoevsky after the The House of the Dead
}

\author{
Decifrando Uma Leitura de Dostoiévsky de Flávio Pereira \\ a partir de A Casa dos Mortos
}

\author{
Nadia Vassileva Nedialkova \\ Bojin Iliev Nedialkov \\ Flavio Santos Pereira \\ University of Brasilia
}

\begin{abstract}
This article provides a "déchiffrage" of the form, style, compositional techniques, and referential musical meanings employed by the Brazilian composer and pedagogue Flavio Santos Pereira in the composition of a seven-part suite entitled Reading of Dostoersky, written in 2016 and based on the book The House of the Dead by Fyodor Dostoevsky. This chamber work is a premonitory work about the present pandemic time, which tests not only the human existential instincts and fears but also the spiritual, philosophical, and moral values upon which a mature and complete personality is built. The author manages to turn the economic structure of a dodecaphonic material into a source of polyphonic, polyrhythmic, stylistic, and timbre diversity. Oscillating and incremental textures, often reaching four-voice overlays, find their counterbalance in the asymmetric movements that synthesize complex subharmonic timbre combinations. The work can be classified as program music, as it employs characteristics of expressionist and impressionist styles mixed with free improvisatory polyphonic techniques. This paper also aims at inducing young performers to consider the paradigmatic model of "déchiffrage" for interpretation supported by stylistic and formal analysis based on classical and modern models. The article includes the full score of Reading of Dostoevsky by Flavio Santos Pereira.
\end{abstract}

Keywords: Brazilian chamber music. Formal analysis of contemporary music. New program music. Analysis for performers.

Resumo: Este artigo apresenta uma "déchiffrage" da forma, do estilo, das técnicas de composição e dos significados musicais referenciais usados pelo compositor e pedagogo Flavio Santos Pereira na composição de uma suíte de sete partes intitulada Uma Leitura de Dostoiérski, escrita em 2016, e que é baseada no livro A Casa dos Mortos de Fiódor Dostoiévski. Esta peça de música de câmara é um trabalho premonitório sobre os tempos atuais da pandemia, que testa não somente os instintos e medos da existência humana, mas também 
os valores espirituais, filosóficos e morais sobre os quais uma personalidade madura e completa é construída. O autor consegue converter a estrutura econômica de um material dodecafônico em uma fonte de diversidade polifônica, polirrítmica, estilística e tímbrica. Texturas incrementais e oscilantes, que frequentemente alcançam quatro vozes sobrepostas, encontram um contrabalanço nos movimentos assimétricos que sintetizam as complexas combinações de timbres sub-harmônicos. A peça pode ser classificada como música programática na medida em que emprega características dos estilos expressionista e impressionista, misturados a técnicas polifônicas de improvisação livre. Este artigo também visa induzir jovens instrumentistas a utilizar o modelo paradigmático da "déchiffrage" para uma interpretação baseada na análise formal e estilística, com suporte em modelos clássicos e modernos. O artigo inclui a partitura completa da obra Uma leitura de Dostoiévski de Falvio Santos Pereira.

Palavras-chave: Música de câmara brasileira. Análise formal da música contemporânea. Nova música programática. Análise para performance.

\section{Introduction}

This paper is the product of an artistic and theoretical collaboration between the two performers and the composer who sign the article. The composer, Flavio Santos Pereira, has an eclectic style. In his works, we find French, German, and Portuguese influences, but above all influences from composers of the Brazilian concert-music tradition-especially Claudio Santoro and Camargo Guarnieri-regarding the lyricism of melodic lines and the exploration of polyphonic textures. Pereira was a student of Claudio Santoro, his advisor during his undergraduate studies in composition and conducting, and with whom he kept close acquaintance until his death in 1989. From Santoro, he inherited especially a taste for experimentation and polyphonic textures, driven by a dynamic formalism averse to the mere reproduction of established models.

His recent composition Reading of Dostoevsky ${ }^{1}$ (2016), for oboe and violin, takes the content and chronology of Fyodor Dostoevsky's The House of the Dead as material for the compositional creative process, following the motto Struggle for the Freedom of the Spirit. Unintentionally, Pereira wrote a premonitory work in relation to the current pandemic situation that led the world into distress on a large scale. The pandemic crisis has locked all of humanity into a huge House of the Dead in which everyday rites are determined by survival instincts. But, as in The House of the Dead, human beings will be able to seek communion with their

\footnotetext{
${ }^{1}$ Available in https://soundcloud.com/user-750505468/sets/leitura-de-dostoievski
} 
own conscience in order to rediscover the freedom of the spirit. Pereira sets Dostoevsky's verbal work into musical images, fulfilling the writer's philosophical message and provoking the listeners to find, for themselves, answers about the meaning of life.

\section{Hypotheses}

In this article, we analyze the musical work Reading of Dostoevsky, seeking to elucidate the main vectors that guided the composer in his creative process. We investigate the roots of the work's formal conception, seeking to unveil the links with tradition and also how tradition is re-signified. Reading of Dostoevsky is conceived in seven movements. The large number of movements led us to the hypothesis that the piece is similar to a dance suite with cyclical form. Although Pereira did not label each movement with a dance title, we demonstrate their analogy with dances found in Bach's suites (Beach 2005).

A second hypothesizes is that Reading of Dostoevsky functions as program music. Indeed, we demonstrate that the composer musically translates the text of The House of the Dead by Fyodor Dostoevsky in its entirety-not only parts or fragments. The work proposes an emotional reading of the text articulated by a musical discourse. The selected quotes, working as a metatext, are intended to create, in the listening process, an imagined emotional synchrony between text and music.

Reading of Dostoevsky is full of symbolism. As the work starts and concludes with the pitch $\mathrm{G}(\mathrm{Sol})$, we assumed that it was a reference to Guido d'Arezzo/Doni's "alphabet". This initial assumption was eventually confirmed, since the work abounds in symbols. There was special care to the use of symbology associated with numerology, assigning specific meaning to musical proportions.

\section{General considerations}

In Reading of Dostoevsky, Pereira presents a unique and unrepeatable stylistic procedure characterized by the intertwining of octaves in thematic presentations of the serial material, generating new permutations from the systematic filtering of the chromatic aggregate. The piece also challenges the 
performers' technical skills. It is characterized by a constant transition between extreme registers, giving the performers unlimited timbre possibilities, which further contribute to the colors of all the other creative techniques advocated by the composer.

Reading of Dostoevsky makes use of a wide palette of textures, ranging from monodic writing to dense polyphony as a result of the interaction of new parts added to complex combinations of composite subharmonic timbres. These principles are applied to the polyphony between oboe and violin in most sections, namely sections $2,4,5,6$, and 7 .

In parallel to polyphony, integrated into an organic whole, the use of polyrhythms is recurrent and developed on the basis of regular and irregular meters. Regarding the work's harmonic content, "it is important that we know how harmonic connections are effected, how harmonic relations interact with voice-leading and melodic functions, and, most important, to realize that harmonic relations are basic to the study of form" (Forte; Gilbert 1983, p. 109). Regarding dissonance, it achieves a symbolic meaning of movement while consonance is associated with a static state.

The composer sought to incorporate and musically express the double plane of the novel, which portrays the drama of the character Alexander Petrovich, but also of Dostoevsky himself (Kirkov 1981). Oboe- and violin-timbre features were used to represent the voices of the soul and the conscience in Dostoevsky's dialogue with himself during his exile. In general, the melodic line of the oboe stands out, embodying the thoughts and feelings of the exiled writerphilosopher. The counterpoint of the violin part portrays an "unshakable" tonal series that represents the cruel reality of a prison.

\section{The Suite form and the embedded programmatic discourse}

The first movement, composed for solo oboe, corresponds to the Prelude of a suite. The oboe is associated with the quote "He was a small man, very thin and pale, ..." (Dostoevsky 2015, p. 13. Our translation). This is how Dostoevsky describes the character Alexander Petrovich, who taught four classes a week to Ivan Ivanovich Gvozdikov's five daughters. Figure 1 shows how Pereira explores the characteristic timbre of the oboe to represent the image of $\mathrm{A}$. Petrovich. 


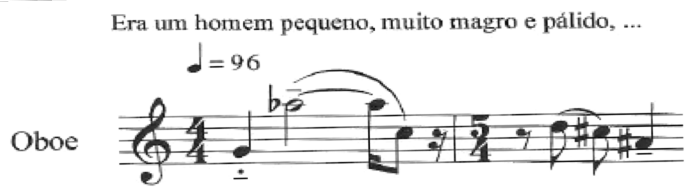

Figure 1: The introductory text connects the oboe with the image of the intellectual prisoner.

The dodecaphonic serial theme is presented four times, in direct relation to the four weekly classes mentioned in the novel, also symbolizing the four years spent in prison. Moreover, it corresponds to the four lessons on life that Dostoevsky received during his exile.

In the Prelude, Pereira has applied the dodecaphonic technique, using a twelve-tone serial theme without repetition. Figure 2 shows the serial theme that the composer adopts in the organization of his work: $G, A b, C, D, C \#, A \#, B, E, E b$, A, F, F\#. This serial theme is subjected to permutations and filtering that go beyond the traditional transformations associated with the dodecaphonic compositional technique.

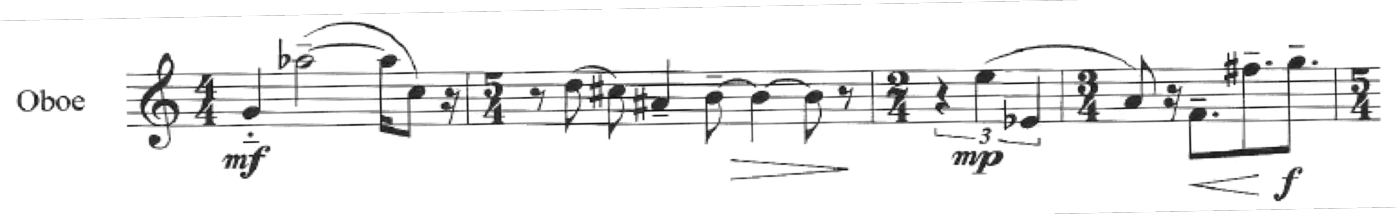

Figure 2: First presentation of the serial theme.

The serialism associated with the use of the dodecaphonic series, strictly followed in the Prelude, leads unmistakably to the symbolic analogy with the rigor of the established order, according to which the day of the condemned exiles, including Dostoevsky, takes place unalterably. This model must be accurately decoded by the performers in order to convey, as clearly as possible, the philosophical basis of the work: the idea of two symbolic layers launched once by the author of the novel and a second time by the composer.

Part of the symbolism and musical semantics can be revealed by examining the meaning of the pitches, taking Guido d'Arezzo's ${ }^{2}$ alphabet as a

\footnotetext{
2 About d'Arezzo, David E. Cohen (2008) writes: "Guido of Arezzo, the most influential music theorist and pedagogue of the Middle Ages, was the author of four extant musical texts, all composed c. 1026 - c. 1033. [...] Guido's teachings represent the culmination of a Northern Italian
} 
reference, with the additions and changes brought by the theorist Giovanni Doni ${ }^{3}$ (1595-1647). According to Figure 2, we observe four motifs in the first exposition of the theme, each one starting and ending with a different pitch of the diatonic scale, bringing a coded message based on d'Arezzo/Doni's alphabet.

1. The first motif starts with $\mathrm{G}(\mathrm{Sol})$ and ends with $\mathrm{C}(\mathrm{Dó})$, meaning: The sun [sol] also looks at God [Deus];

school of music theory and pedagogy, the most important representative of which (apart from Guido himself) is the Dialogus de musica, also known as Enchiridion musices ('Handbook of Music'). Formerly attributed to the Abbot Odo of Cluny (d. 942), it was compiled c. 1000 by an anonymous Lombard monk now known as 'Pseudo-Odo.' The Dialogus is a source for much of Guido's teaching, particularly in his principal treatise, the Micrologus. [...] The basis of Guido's method was to have the student singer learn to recognize and produce the notes of the scale by associating each with a melodic phrase that starts with that note and thus provides a mnemonic for the intervallic relations of that note to the notes around it. He used for this purpose the hymn Ut queant laxis, each of whose first six short phrases begins with a different note, in ascending order by step, starting from $\mathrm{C}$.

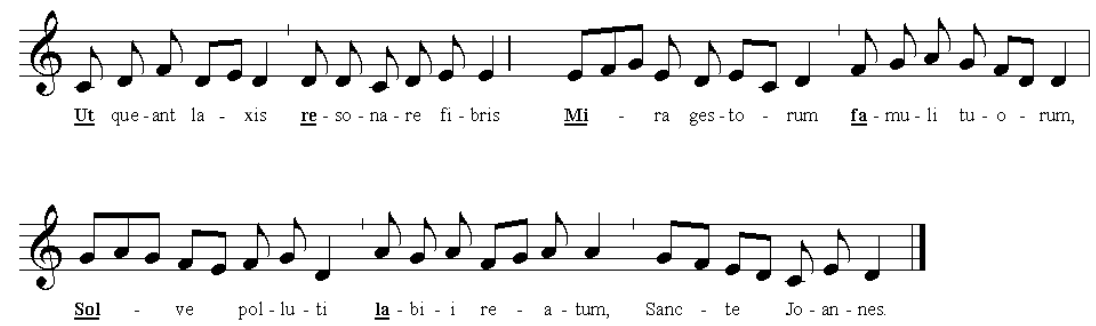

Closely associated with hexachordal solmization is another, equally celebrated pedagogical device that was universally attributed to Guido, although no extant text by him mentions it: the Guidonian 'hand' (manus). Each 'place' of the gamut (the littera plus vox or voces for each note) was visualized as occupying a position on one of the joints or fingertips of the left hand. [...] Finally, we must mention the most important of all the innovations ascribed to Guido, and one in which he certainly played an early and significant role: staff notation" (p. 339, 341, and 344)

${ }^{3}$ According to Hodges (2021), "Giovanni Doni changed the name of the root tone from ' $\mathrm{Ut}$ ' to 'Do,' and added Si, which d'Arezzo did not recognize as a scale tone (p. 1). [...] Doni mnemonicized the note names as abbreviations of the following Latin words (mnemonicization was a favorite trope since ancient times of the "method of symbols", in which one series of things is theosophically associated with another, thereby enriching both for the mind's contemplation):

Do - Dominus, Lord, i.e. God

$\mathrm{Si}$ - Sider, star, the siderial world. all galaxies

La - Lactae, milk, our Milky Way galaxy

So - Sol, Sun

$\mathrm{Fa}$ - Fata, fate. Fate is ruled by the planets, hence $\mathrm{Fa}$ is the planets.

Mi - Microcosmos, the small universe, the Earth.

Re - Regina Coeli, Queen of the Heavens, the Moon.

Do-Dominus" (p. 2). 
MUSICA THEORICA Revista da Associação Brasileira de Teoria e Análise Musical 2020, v. 5, n. 2, p. 303-330 - Journal of the Brazilian Society for Music Theory and Analysis@ TeMA 2020 - ISSN 2525-5541

2. The second fragment begins with $\mathrm{D}(R e$ ) and ends with $\mathrm{B}(\mathrm{Si})$, meaning: Matter [Matéria] ascends to Heaven [Céu];

3. The third fragment begins with $\mathrm{E}(\mathrm{Mi})$ and ends in A (Lá), meaning: The Miracle [Milagre] of the Milky Way or The Miracle of the Stars [Estrelas];

4. The fourth and final motif begins with F (Fá) and ends with G (Sol), meaning: The seven planets look at the Sun [Sol].

We emphasize that the work has seven movements and all thematic materials are developed aiming at the brilliant ending, establishing a close relation with Dostoevsky's work that links all sections into an organic musical discourse.

The closed cycle of the theme presented with 13 pitches, as shown in Figure 2, starts and ends with G (Sol-Sun), symbolizing the day in prison, where the prisoners' eyes see the sunlight only in the early morning and at the end of the afternoon. The sunlight is absent throughout the course of the day and is absent too in the soul of the writer-philosopher, as well as in the reality of the prison cell and during torture. It should be noted that Pereira approached this undisturbed cyclical aspect of the day in prison in a similar way. The work opens the first movement with the note G (Sol - Sun), in the oboe, and ends the last movement again with the pitch of the "Sun", but this time on the violin's G string, harmonically combined with E-flat on the fifth octave played by the oboe. We interpret this consonant ending as a symbol of freedom, since all other movements end with other pitches of the dodecaphonic order in highly dissonant combinations.

In the first section, each presentation of the series is fragmented in a different number of motivic cells. The first presentation is divided into four motivic cells (as discussed above), the second into three, the third into two, and the fourth into five. This way, the real culminating point ${ }^{4}$ is found in the third and denser presentation of the theme. The culmination is marked by an accelerando, compensating for the first of this presentation's two fragments, which starts with a slower tempo (Più Lento).

It is not by chance that the real culminating point is placed exactly on the movement's golden ratio: 1/1,618. In a retrograde version of the same golden

\footnotetext{
${ }^{4}$ We are referring to the "logical and real" (rhetorical) culmination of the movement and not to the melodic culmination. At this moment, we have a concentration of rhythmic and motivic culminations (stretto) in the third presentation of the theme series.
} 
ratio, this time from the end to the beginning of the movement, the location of the melodic climax happens on A, stressed by fortíssimo dynamics, highlighting the highest pitch of the fourth octave.

This analysis of the first part clarifies the main creative idea of the composer. It is known that, in most cases, the first movement, and particularly its exposition section, carries the "DNA" of the entire work, serving as a deciphering key to the "correct" interpretation of the principles incorporated by the composer.

The second movement corresponds to the Allemande, which in the Renaissance and Baroque periods was often performed by a small group of performers. After the Prelude, for solo oboe, this second movement is, in fact, the first duet of the work, in a possible allusion to the Renaissance and Baroque practice.

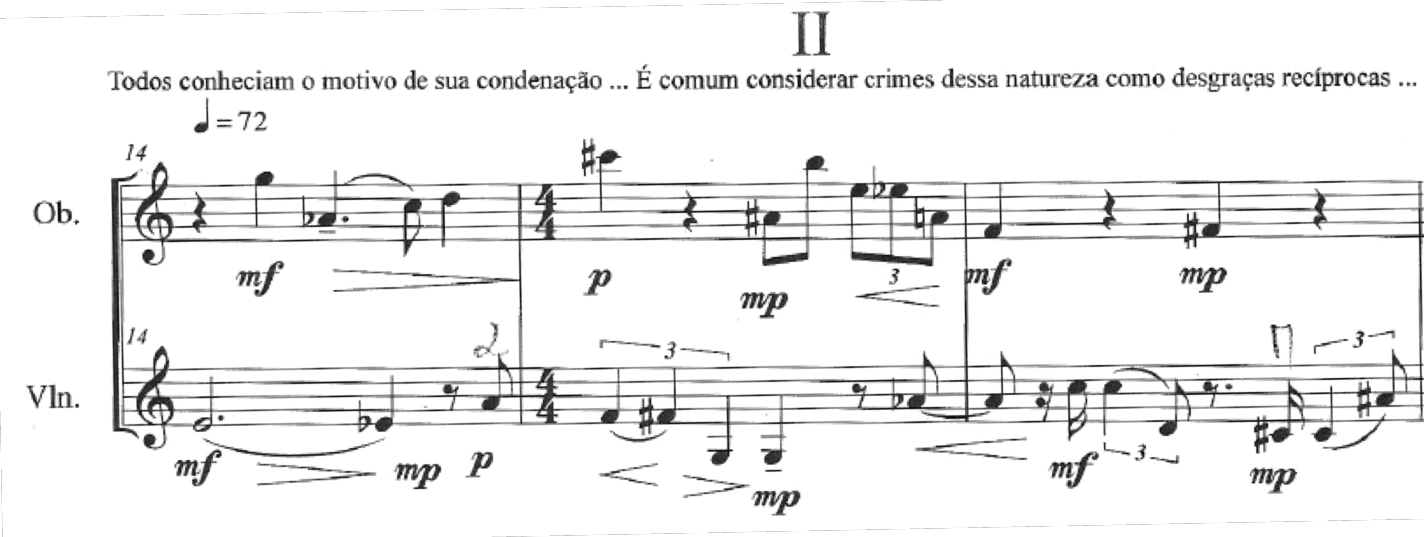

Figure 3: Opening of the second movement, interpreted as an Allemande.

Figure 3 exemplifies the first polyphonic exposition of the dodecaphonic serial theme in free improvisational style. The complementary rhythm and asymmetrical polyrhythmic combinations enhance the aggressive confrontation between the angular melodic lines of the oboe and the violin.

An excerpt from Dostoevsky is appended to the musical text: "Everyone knew the reason for his conviction... It is common to consider crimes of this nature as reciprocal misfortunes..."5 (Dostoevsky 2015, p. 13. Our translation).

\footnotetext{
${ }^{5}$ Everyone knew the reason for his conviction: to have killed his wife out of jealousy, a year after getting married, giving himself up soon after the crime, a fact that had helped him to lessen the penalty. It is common to consider crimes of this nature as reciprocal misfortunes - for the victim and for the criminal - , later forming an atmosphere of compassion and tolerance.
} 
MUSICA THEORICA Revista da Associação Brasileira de Teoria e Análise Musical 2020, v. 5, n. 2, p. 303-330 - Journal of the Brazilian Society for Music Theory and Analysis @ TeMA 2020 - ISSN 2525-5541

In his text, Dostoevsky uses his novelist techniques to indirectly, through his character, attribute to himself a supposed domestic crime, avoiding describing the real reason for his exile, which is of political order. The polyphonic texture composed by the lines of the oboe and the violin expresses, in a deeper philosophical level, the inner struggle of the "fallen" writer-philosopher.

The third movement is a reminiscence of a Sarabande, with its standard form in three sections. The Sarabande has its origins as a Spanish folk-dance in the $16^{\text {th }}$ century, with characteristics of Moorish influence. We note also that the performance of Sarabandes in funeral rites is frequent. At the end of the third movement, for solo violin, Pereira "buries" the supposed fleeting hero Alexandre Petrovich, "killed" by Dostoevsky to "leave him" with the pitches of The House of the Dead.

In the last five bars, as shown in Figure 4, the composer literally represents the ceasing of the character's life, as the theme's pitches begin to catch up with each other, turning into agonizing vertical dissonant chords and intervals, symbolizing the uneven beats of the dying heart. The movement ends with the weakening (decreasing) of the continuous line in a diminished octave, equivalent to a major seventh.

Numerology helps to clarify the musical semantics of this passage: eight, the number of life, becomes seven, expressing that "only the soul remains in its eternal rest".

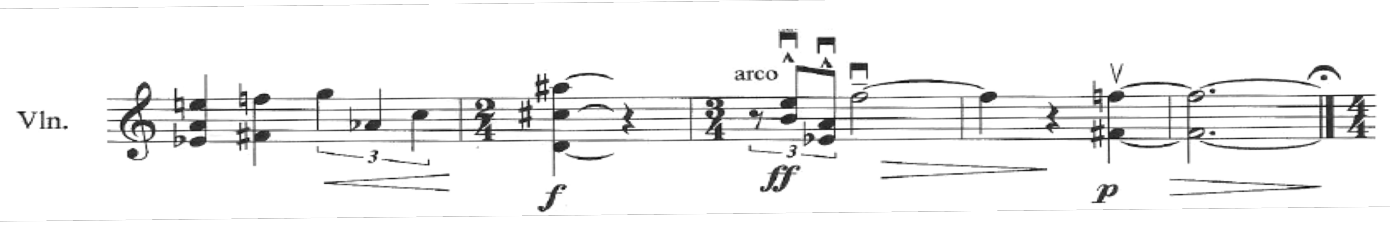

Figure 4: End of the third movement, a Sarabande; the passage symbolizes the death of Alexander Petrovich.

The third movement is associated with other text fragments: "I got news from her about his death and I got an old basket with his papers ${ }^{6}[. .$.$] I found a$

\footnotetext{
${ }^{6}$ "Circumstances forced me to stay away from the city of $C$ for months. I returned in the middle of winter and one of the first things I found out was that this Petrovitch had died in early November, without medical assistance or friends.

Such a death was almost forgotten, just a few months later. And the rooms where I had lived were still vacant. I went to see them, more as an excuse to see the old woman. By giving a
} 
full pile [...] in a small handwriting ${ }^{7}[\ldots]$. In that text [incomplete] lined up ${ }^{8}$ [bizarre cases, sometimes candid memories, written in a nervous style, highly personal, also full of paroxysms $\left.{ }^{9}\right]^{\prime \prime}$ (Dostoevsky 2015, p. 15-16. Our translation). This is the penultimate text fragment annotated by the composer, whose developments unfold in the third, fourth, fifth and sixth movements of the music.

To perform this piece, the relationship between text and music must be mapped. The complete implied text, to which Pereira alludes with three incomplete quotations, has to be found and analyzed. The quoted fragments are: bizarre cases, sometimes candid memories, written in a nervous style, highly personal, also full of paroxysms. Once the performers are aware of the meaning of these quotations, they can design the character to be informed through the music.

The fourth movement is associated with the Loure, appearing as a slow Giga in three parts, in the form: A-B-A'. This is followed by a faster Courante in the central part, which can also be defined as a variation, or Double. The third section re-presents the Loure dance. In this fourth movement, the emphasis is again on polyphony, polyrhythmic, and dodecaphonic development of the thematic material, going from two to three voices. The compositional technique featured in this movement is the dialogical opposition between the oboe and the violin.

twenty-kopeck coin, I got news from her about his death and I got an old basket with his papers" (Dostoevsky 2015, p. 15. Our translation).

7 "I took the papers with me and spent the whole day putting them in order. Three-quarters were indecipherable or occasional notes and corrected lesson notebook sheets. Finally, I found a full pile from first to page three hundred and something in a small handwriting. Certainly, the author did not want or could not finish the narrative that took place there, addressing precisely the life he had led in prison for ten years"' (Dostoevsky 2015, p. 15-16. Our translation).

8 "In that text incomplete lined up bizarre cases, sometimes candid memories, written in a nervous style, highly personal, also full of paroxysms. I reread those memoirs a number of times and ended up coming to the conclusion that this work should have been written in the midst of crises and attacks of mental alienation. I have for myself that those writings about the prison - The House of the Dead, as the narrator himself in a certain passage calls them..." (Dostoevsky 2015, p. 16. Our translation).

${ }^{9}$ Paroxysm: a sudden and severe attack of acute physical pain. Sudden attack of strong emotional excitement and its outward manifestation, fainting. Acute form of feeling experience. 
The fifth movement resembles a Minuet. However, instead of the normative trio, there is a faster central part with a characteristic impressionist character, as illustrated in Figure 5.

Ob.

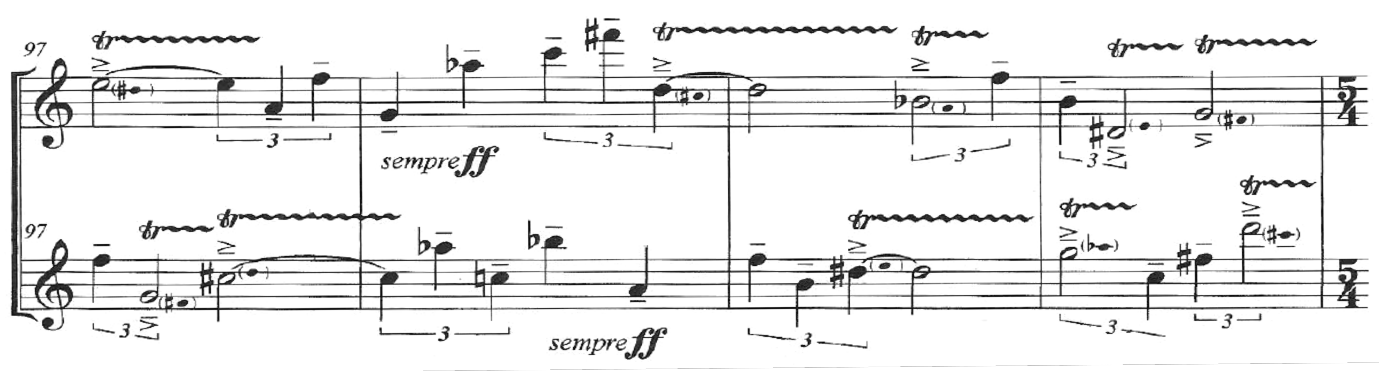

Figure 5: Central part of the fifth movement, evoking an impressionist character.

The overflowing trills, from oboe to violin and vice versa, refer to Benjamin Britten's program work for solo oboe, entitled Arethusa, one of Ovid's metamorphoses. It should be noted that the author has achieved an extremely vivid stylistic contrast through the eclectic opposition between the expressionistic style (reminiscent of Schoenberg or Berg) (Yapova 2011) of the first and third parts, and the refined impressionistic style of the central section, nevertheless always following the dodecaphonic technique applied to the main serial theme. The architecture of this fifth movement is based on two and three voices counterpoint.

The sixth movement employs the Siciliana form. The violin initiates the movement in the role of accompanist, from which erupt elaborated melodic lines in one and two voices. These are characterized by long notes. In turn, they are interrupted by passages similar to arpeggios unfolded on the four strings of the violin, to resume the role of accompanist, in allusion to the movement of the waves of the sea. This vivid imagery reflects an exiled man state of mind, who sinks into the deep waters of despair but now returns and, with his last forces, stays on the surface of the sea to take a breath: "... I ended up coming to the conclusion that this work should have been written in the midst of crises and attacks of mental alienation" (Dostoevsky 2015, p. 16. Our translation). The beginning of the movement summarizes all these observations, as illustrated in Figure 6. 


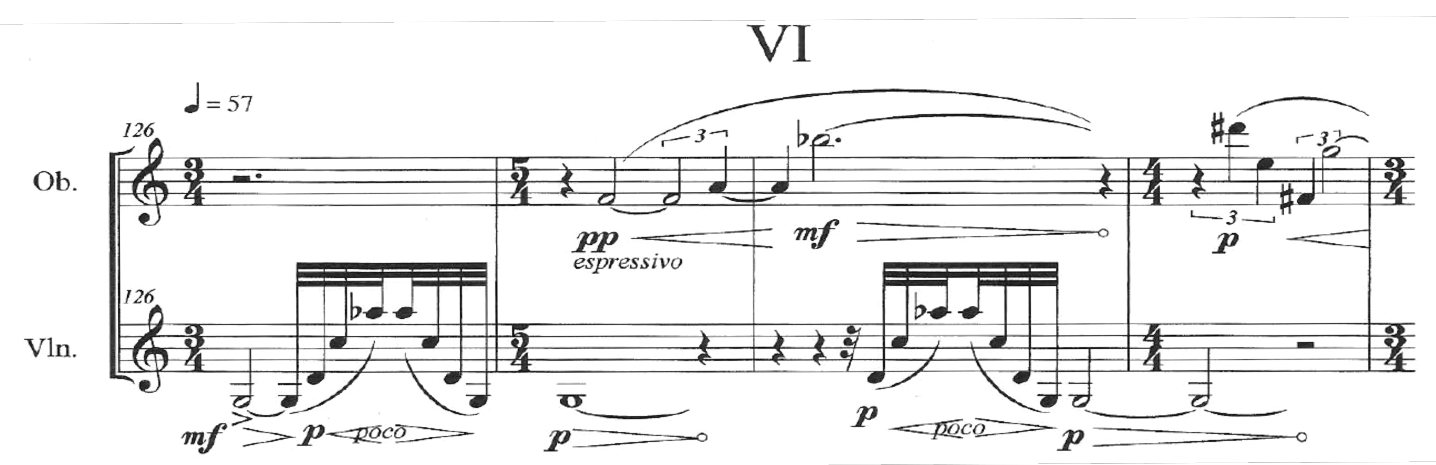

Figure 6: The beginning of sixth movement that features a Siciliana

The oboe angular line, presented in the upper voice, conducts a dialogic melody reminiscent of crying, moaning, and screaming, which further accentuates the dramatic character of the movement. This Siciliana is the dramatic culmination of the work.

The seventh and last movement corresponds to a Giga. It has a fast and moving character. Figure 7 shows the spectacular end of the work, that finishes in the "solar" pitch G, in consonance with an E-flat in the oboe. The seventh movement consists of three parts. The first part contains 17 bars. This is a number that can be associated with the idea of resurrection, as tradition has established since ancient times. The second, slower part is built in 8 bars, with the number eight symbolizing the word life. 10

The last part consists of 19 measures. Here again we find a number that can be related to Solomon's square numerology (Luna 2019). The number 19, which is positioned vertically, means the new birth. This fully corresponds to the text of the program borrowed by Pereira, quoting Dostoevsky, after the end of this last part, to serve as a conclusion: "The chains fell to the ground... I couldn't believe it wasn't on my ankles ... Freedom, new life, resurrected ${ }^{11}$ of the dead ... What a glorious moment!". Here, Pereira once again suppresses phrases from the original in the program text. Recalling the original text can help to clarify the musical discourse: "[...] I left the prison never to return. [...] first we went to the blacksmith, so he could take our chains off [...]. The chains fell to the ground. I got them [...]. I wanted to hold them, look them over, one more time. Amazed, I

\footnotetext{
${ }^{10}$ On the symbolisms of numbers 17 and 8, see, respectively, Schimmel 1993, p. 219-221 and p. 156-163.

11 "Risen from the dead". The original text emphasizes the word resurrected.
} 
couldn't believe it wasn't on my ankles anymore. [...] Yes, with God! Freedom, new life, resurrected of the dead [...]. What a glorious moment!" (Dostoevsky 2015, p. 295. Our translation).

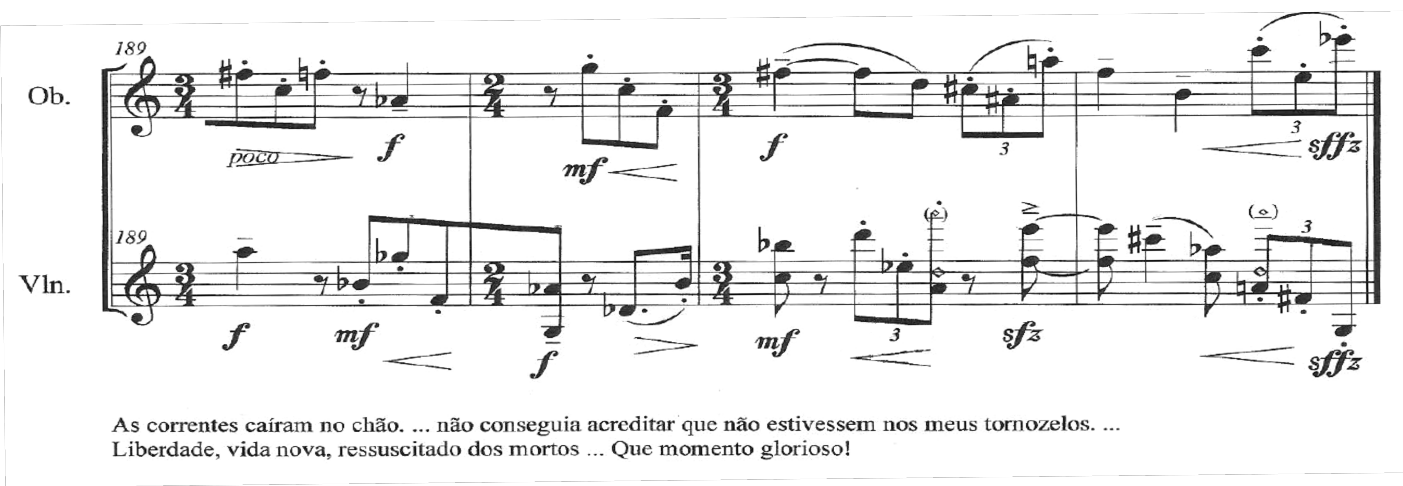

Figure. 7: Seventh movement - Giga

The composer deliberately omits the exclamation from the text "Yes, with God!". He leaves to the performers and listeners to discover it by themselves and seems to very gently invite them: "Choose, but yourself, of your own free will - The Liberty, the New Life and the Resurrection".

\section{Conclusion}

The composition of the seven sections of Reading of Dostoersky allowed the authors of this article to glimpse the possibility of linking the music with both the Baroque Suite and the use of numerology as one of the supports in the development of the specific musical semantics for this work. The associations with the Suite are mainly due to the stylistic character of the movements, more than to the adherence to specific dance meters, which have been stylized since the Baroque period. We found that the association was convincing, and, more than that, enlightening. The number seven symbolizes wholeness, perfection, consciousness, and spirituality. It also symbolizes cyclical completion and renewal. In addition to the organization in seven sections-seven also symbolizes the pursuit of learning and perfection - we believe that numerology has an important symbolic role in the definition of the formal proportions of this composition, what was allowed to reach a quite convincing evidence in the seventh movement. 
Although the texture of Reading of Dostoevsky is densely chromatic, we were able to demonstrate that Guido d'Arezzo's diatonism plays a crucial symbolic role, including the way in which the motifs of the serial theme are contoured since the first movement.

Reading of Dostoevsky is a syncretic work in which we distinguish a new style of chamber music. It appropriates the large-scale achievements of the polyphonic era, the revived nineteenth-century program style, serialism, dodecaphony, expressionism, impressionism, $20^{\text {th }}$-century polyrhythms, reaching the $21^{\text {st }}$ century in search of consonant combinations between resulting subharmonics $^{12}$ and high-overtone constructions expressed in ethereal translucent virtual texture in the background space, created by the specific timbre characteristics of the oboe and the violin.

Like in Berg's compositions (for instance, in the Lyric Suite), Reading of Dostoevsky strives for the concise representation of musical and extra-musical ideas. Indeed, Pereira makes a successful attempt to present a large-scale generalization of musical styles and techniques associated with philosophical existential principles that inspire art creators of all ages.

Therefore, Reading of Dostoevsky is not just a representation of Fyodor Dostoevsky's drama The House of the Dead. From that drama the composer derives a message and a synthesis of inspiration, spiritual sublimity, and deep international humanism.

\section{References}

1. Beach, David. 2005. Aspects of Unity in J. S. Bach's Partitas and Suites. Rochester: University of Rochester Press.

2. Cohen, David. 2002. Notes, scales, and modes in the earlier Middle Ages. In T. Christensen (Ed.), The Cambridge History of Western Music Theory, p. 305363. Cambridge: Cambridge University Press.

3. Dostoevski, Fyodor. 2005. The House of the Dead. Sofia: Zahariy Stoyanov.

4. Dostoiévski, Fyodor. 2015. Recordações da Casa dos Mortos. Nicolau S. Peticov (Trad.). São Paulo: Ed. Nova Alexandria.

\footnotetext{
${ }^{12}$ Low "undertones" caused by symmetrical coincidences of wave phases of two higher pitches. This phenomenon of musical timbre is called: resultant harmonics or resultant subharmonics.
} 
MUSICA THEORICA Revista da Associação Brasileira de Teoria e Análise Musical 2020, v. 5, n. 2, p. 303-330 - Journal of the Brazilian Society for Music Theory and Analysis @ TeMA 2020 - ISSN 2525-5541

5. Forte, Alan; Gilbert, Steven. 1983. Introduction to Schenkerian Analysis. New York: W.W. Norton and Company.

6. Hodges, Richard. 2021. Theosophy of the musical scale. http://www.richardhodges.com/TheosophyOfMusicalScale.pdf. Retrieved on August 17, 2021

7. Kirkov, D. 1981. The turning point in Dostoevsky and "The House of the Dead". In Fyodor Dostoevsky, Collected works, v. 3. Sofia: Narodna Kultura.

8. Luna, Jairo Nogueira. 2019. Desvendando os Segredos da Chave de Salomão. Revista Diálogos, n. 21. Garanhuns: Universidade de Pernambuco.

9. Schimmel, Annemarie. 1993. The Mystery of Numbers. New York: Oxford University Press.

10. Yapova, Natasha. 2011. Second Wiennese School: Schoenberg, Webern, and Berg. Sofia: Mars 09 EOOD. 


\title{
Leitura de Dostoiévski
}

\author{
Oboé e Violino
}

\section{Flavio Santos Pereira}

\author{
13jan-11fev2016
}




\section{Leitura de Dostoiévski}

para oboé e violino

I
Flavio Santos Pereira 13jan-11fev2016

Era um homem pequeno, muito magro e pálido, ...

$$
\downarrow=96
$$

Oboe
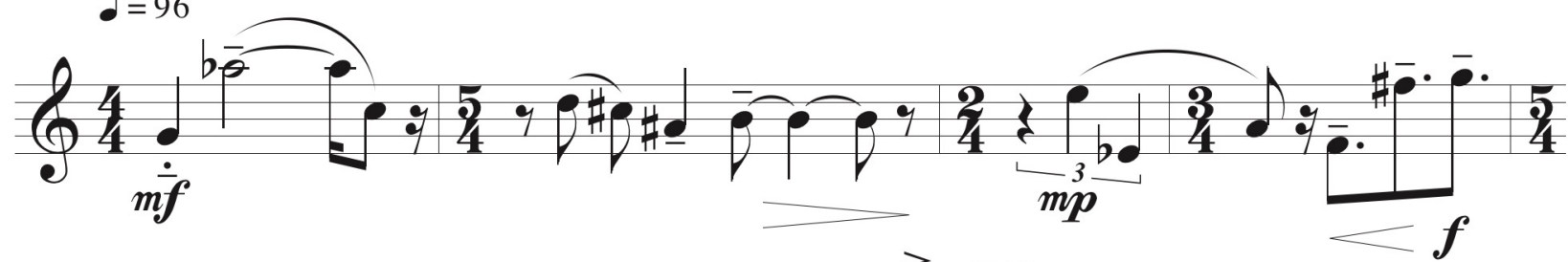

$\mathrm{Ob}$

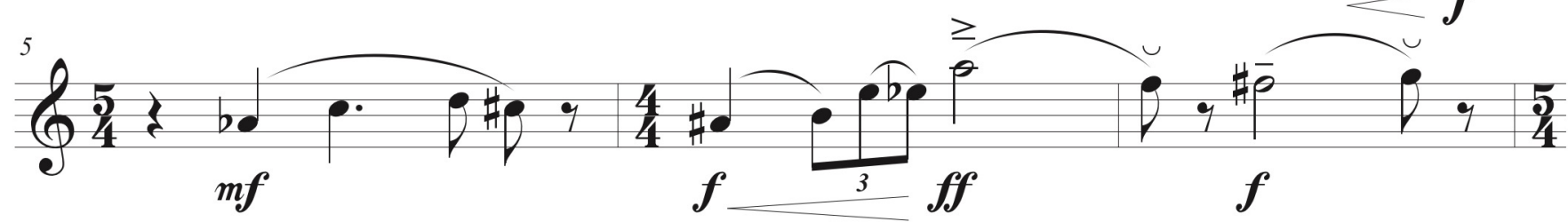

più lento $d=60$ accel. $\ldots \ldots \ldots \ldots \ldots \ldots+\ldots \ldots$

$\mathrm{Ob}$.

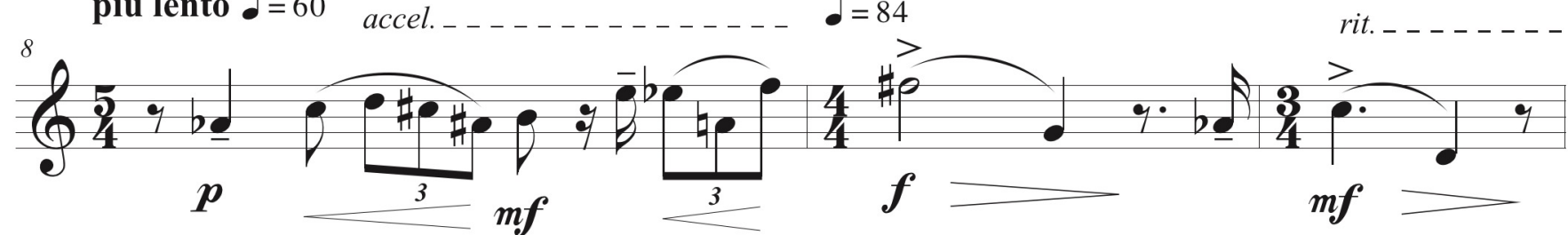

$\mathrm{Ob}$.

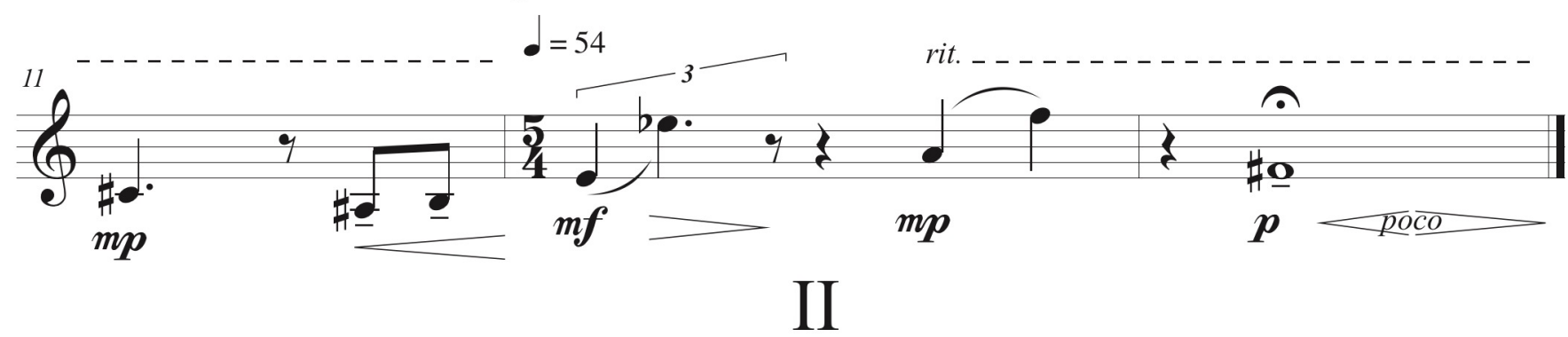

Todos conheciam o motivo de sua condenação ... É comum considerar crimes dessa natureza como desgraças recíprocas ...

$d=72$

$\mathrm{Ob}$.

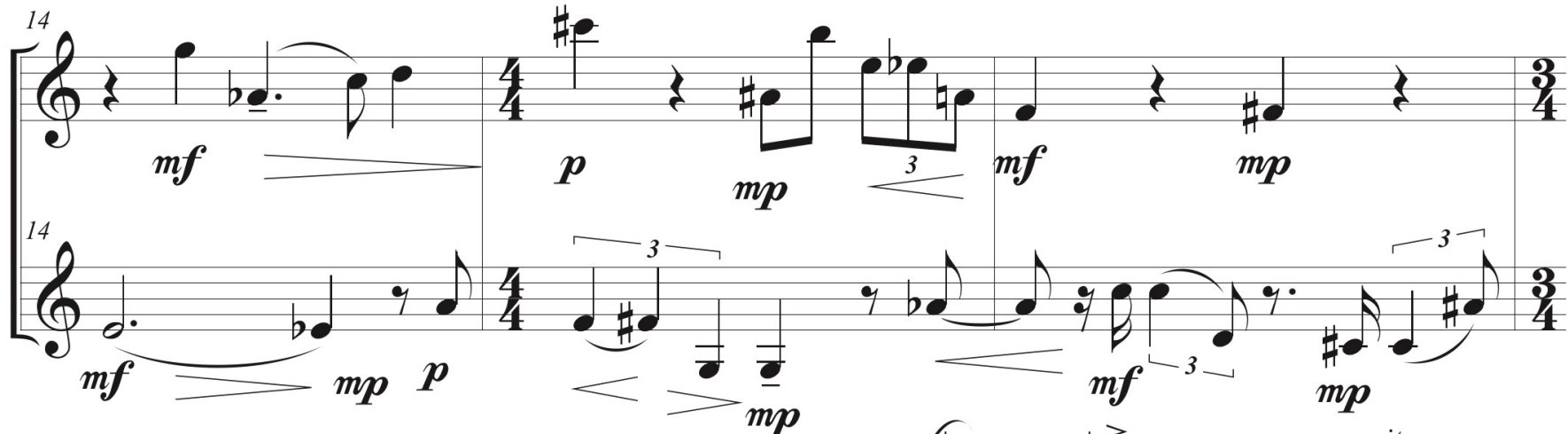

Vln.

$m p$

$\mathrm{Ob}$.

Vln.

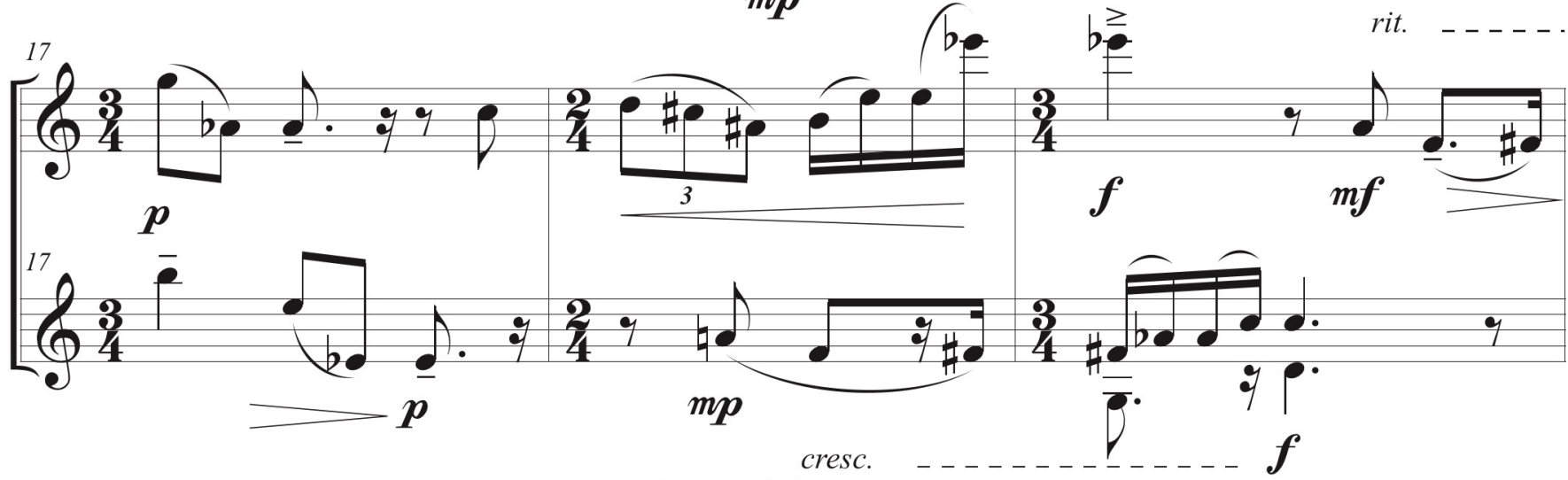

(C2016 Flavio Santos Pereira 


$$
\downarrow
$$

$\mathrm{Ob}$.

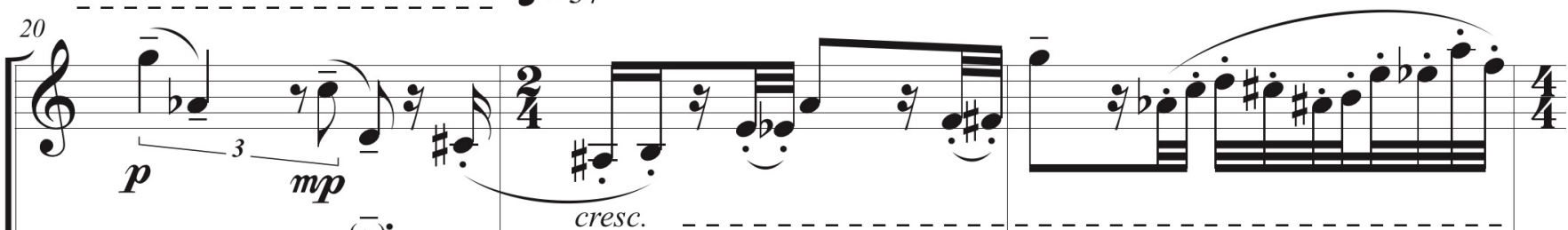

Vln.
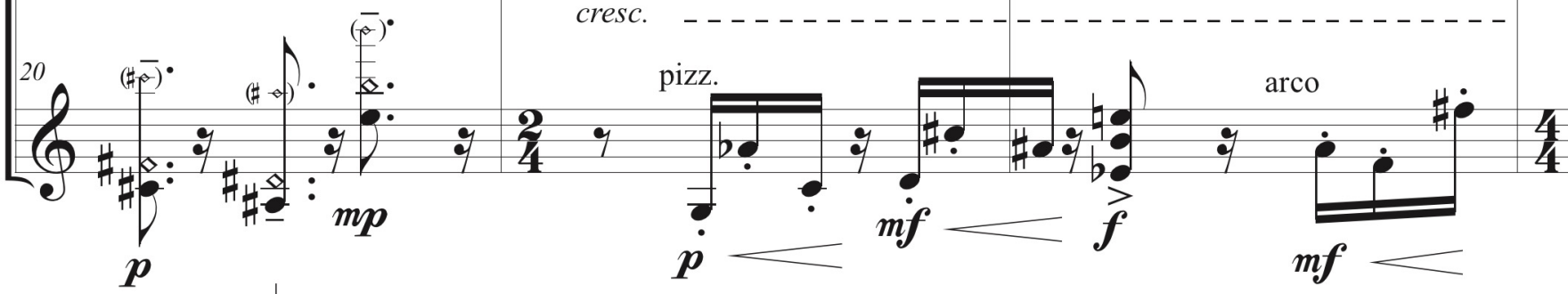

$\mathrm{Ob}$.

Vln.

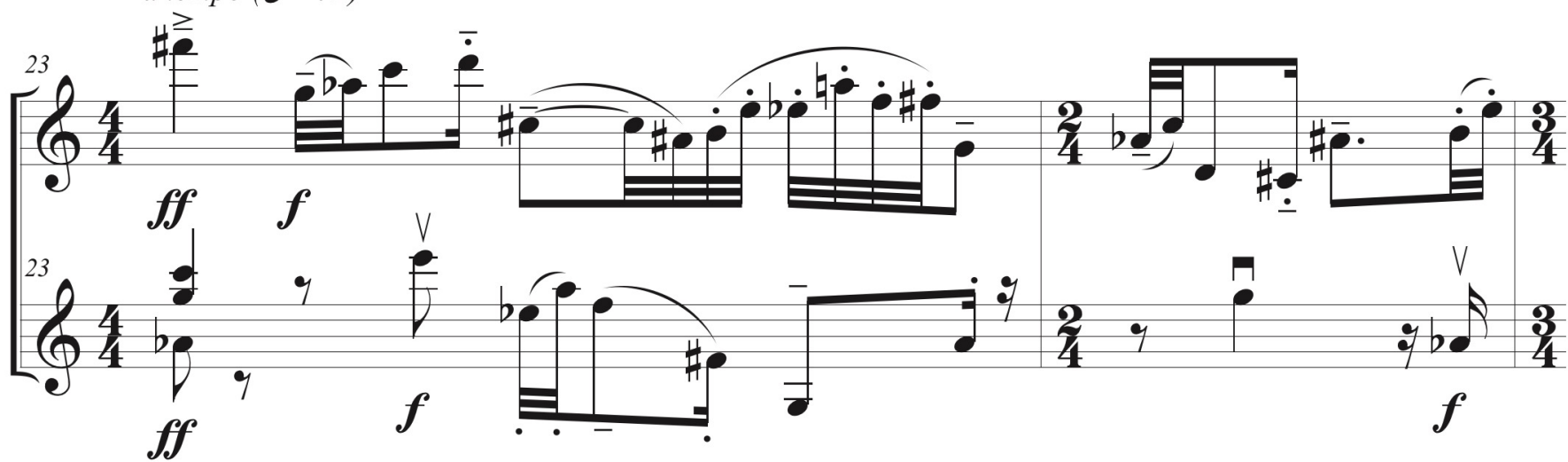

Ob.

Vln.

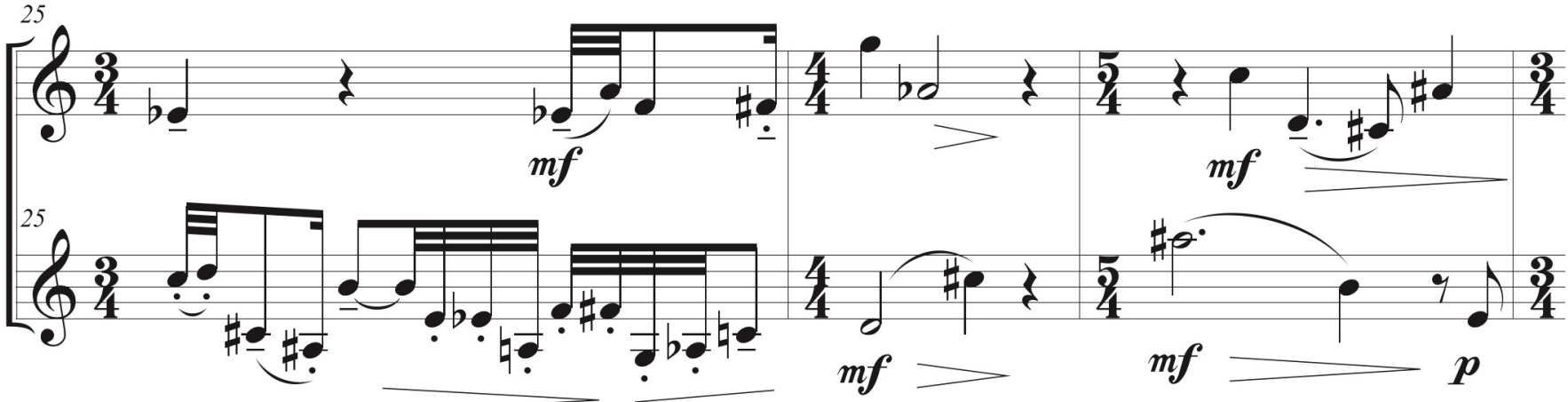

$\mathrm{Ob}$.

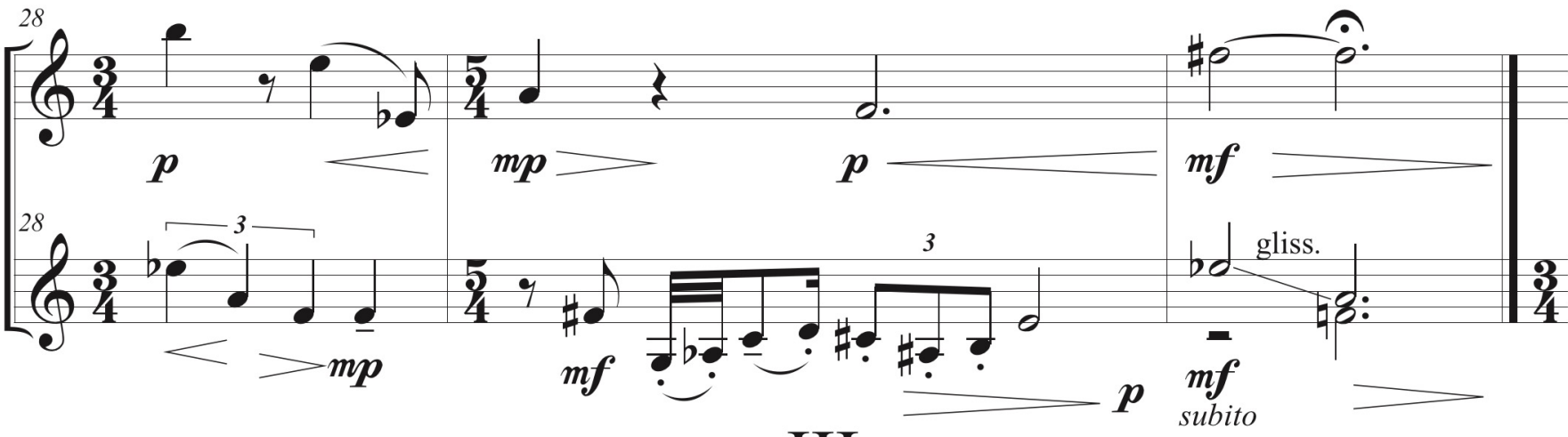

III

... consegui dela notícias sobre o falecimento e ganhei uma cesta velha com papéis dele. ... encontrei um calhamaço cheio ... com uma letra miúda. ... Naquele texto se alinhavam ...

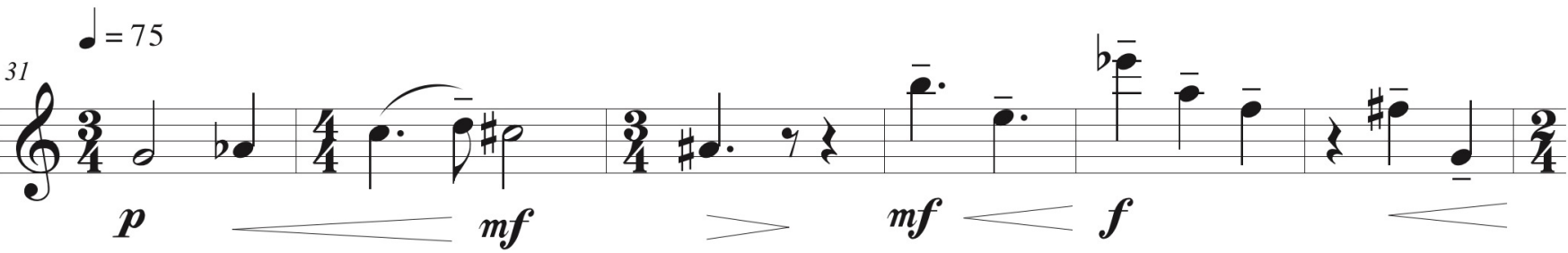




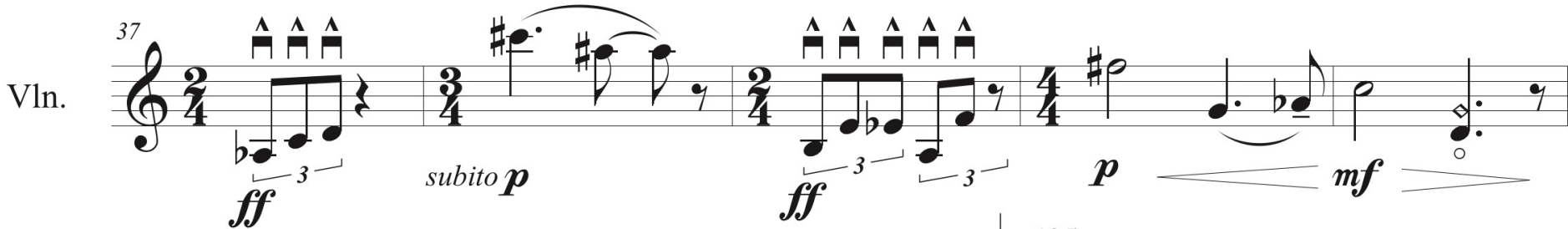

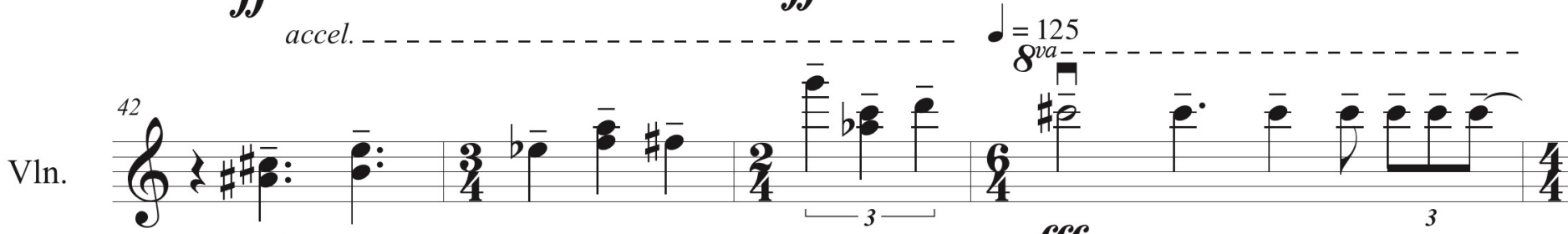
$\boldsymbol{m} \boldsymbol{f}$ fff

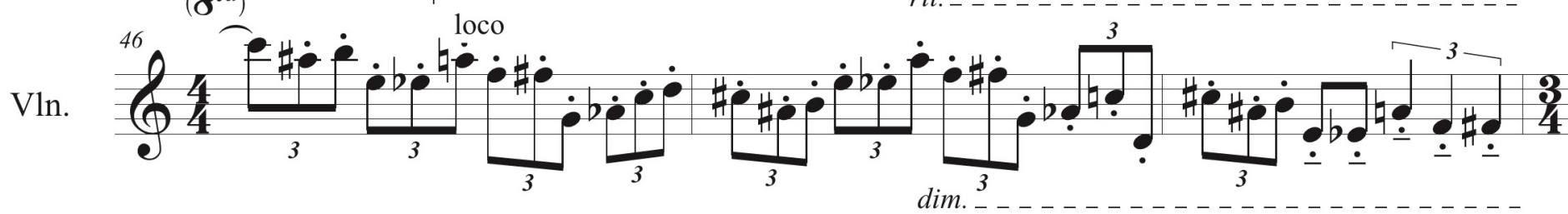
$=75$

$$
\text { ๖ }=125
$$

$d=75$

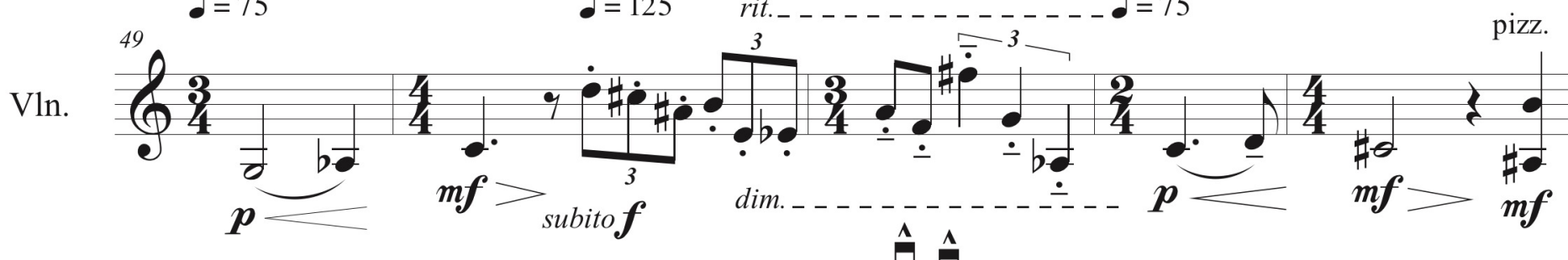

Vln. $\downarrow-93$

\section{IV}

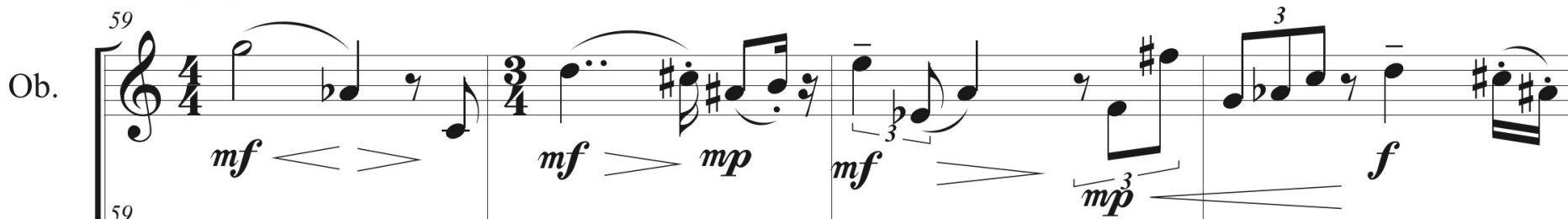

Vln.

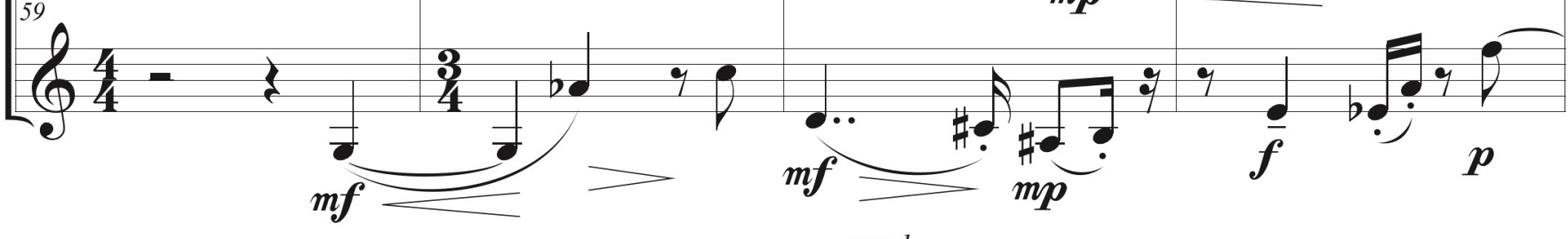
accel.

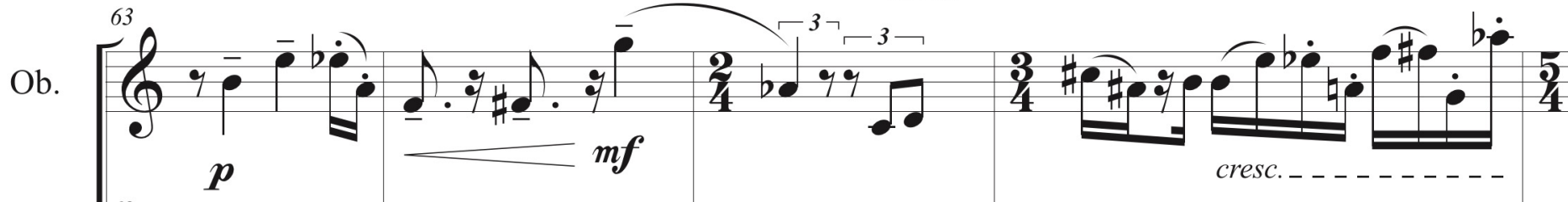

Vln.

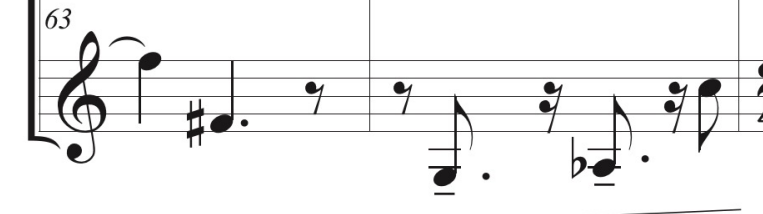

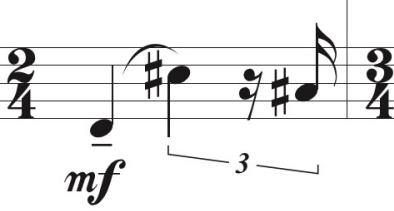
$m \boldsymbol{f}$ 


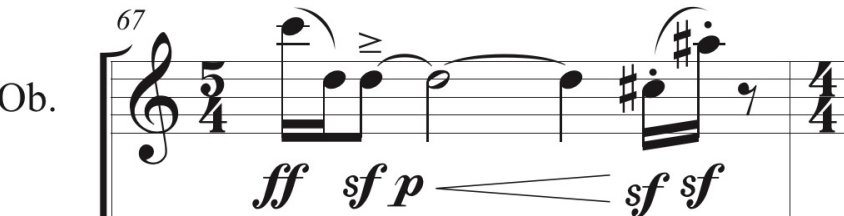

$\bullet=117$

Vln.

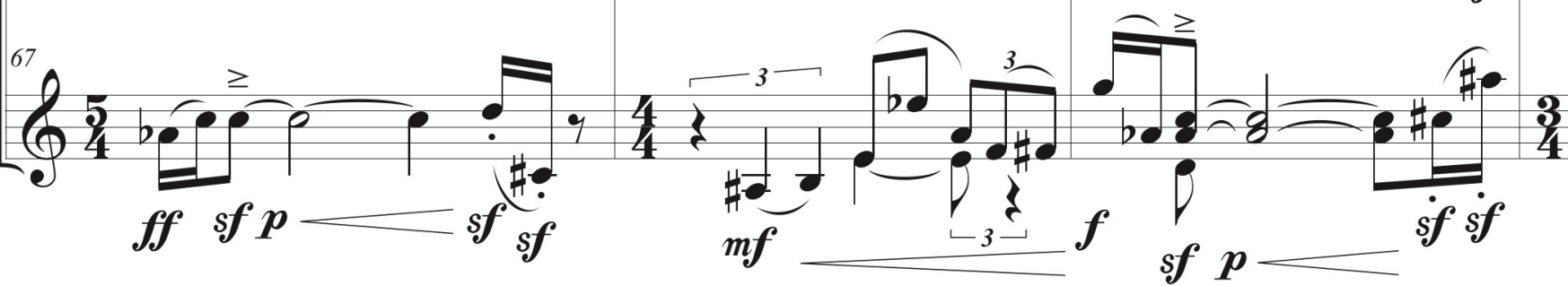

$\mathrm{Ob}$.
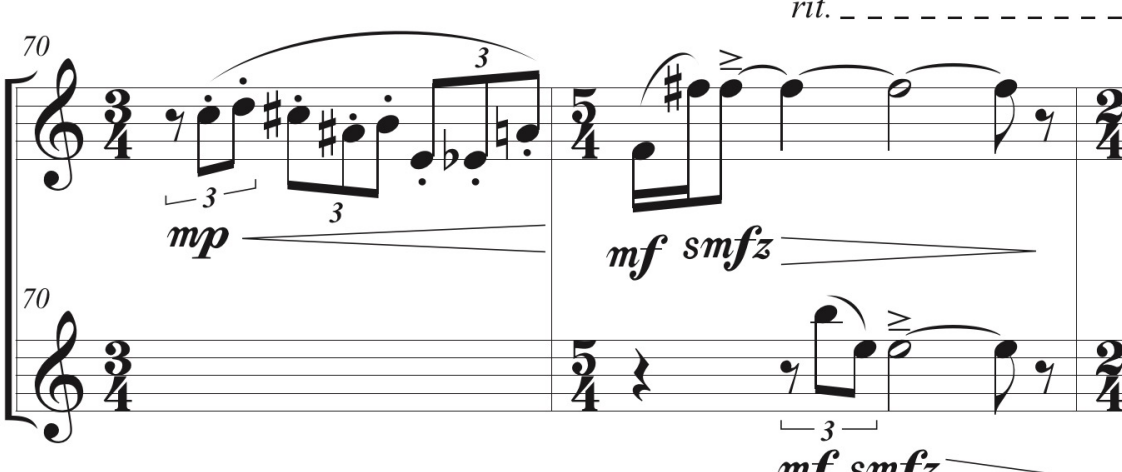

$=93$

Vln.<smiles>c1ccoc1</smiles>

$$
m f s f_{z}
$$

m.

$m p$

$\boldsymbol{m} \boldsymbol{f}<=$

$\mathrm{Ob}$

Vln.

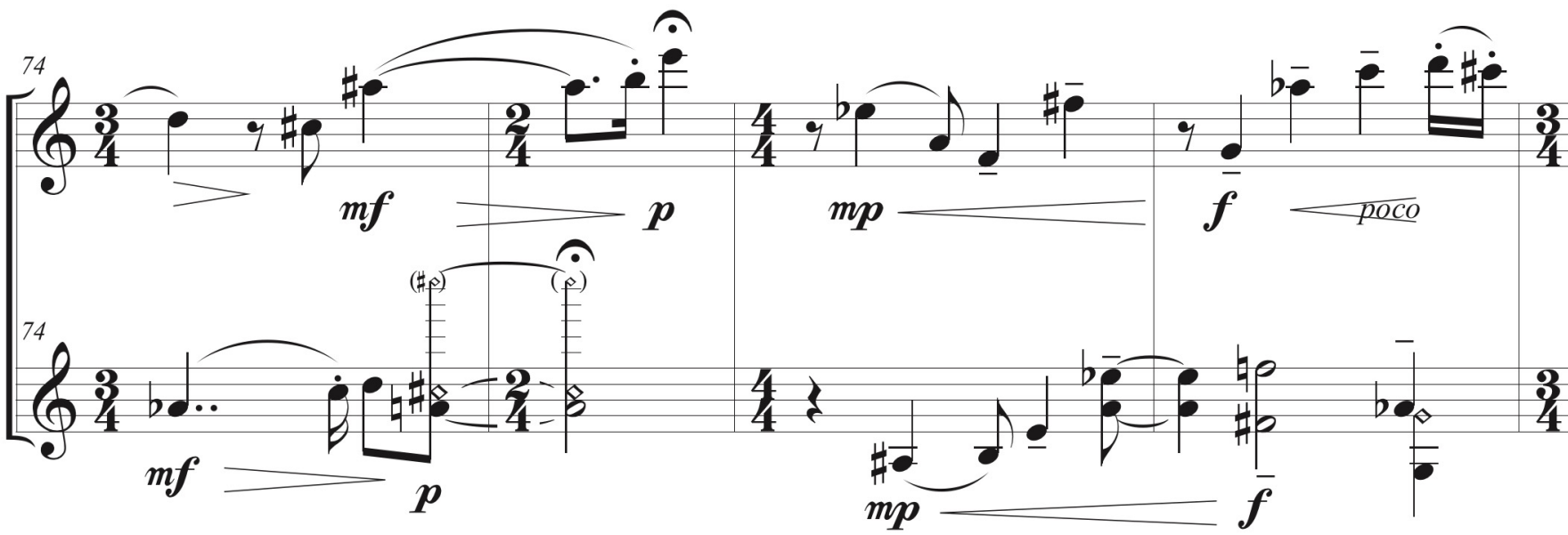

$\mathrm{Ob}$.

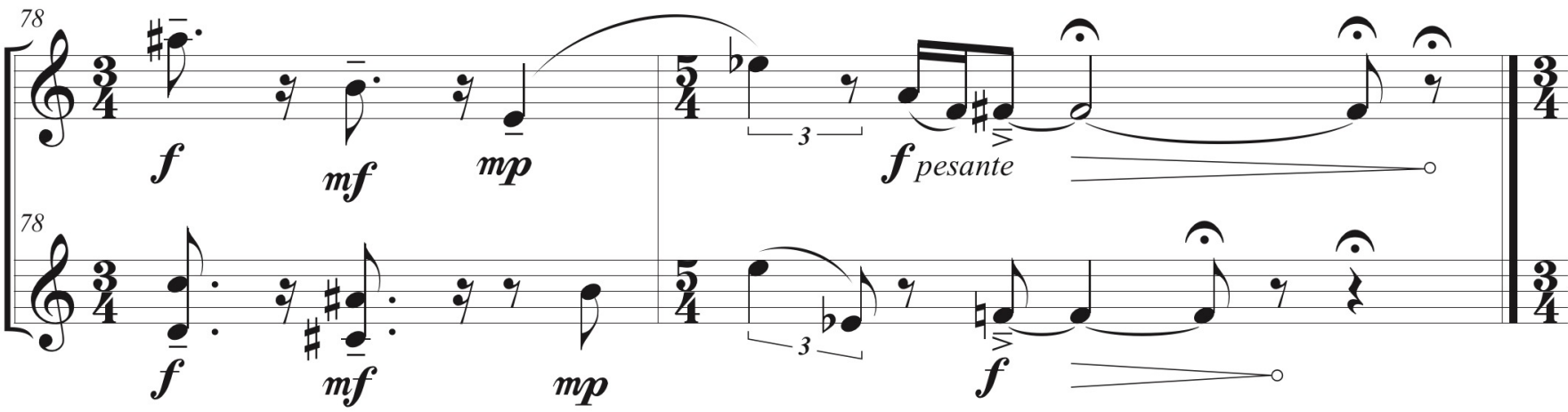



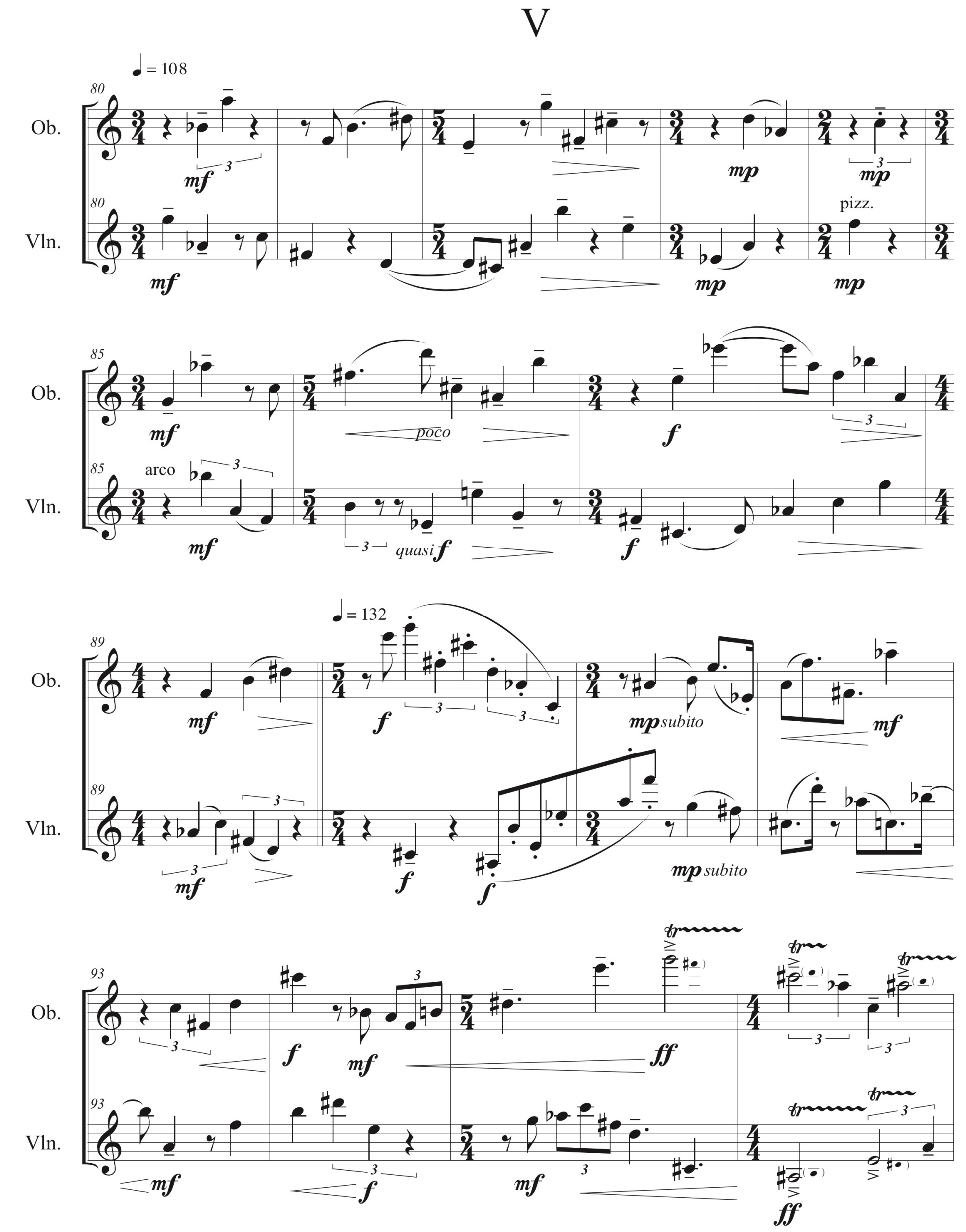
$\mathrm{Ob}$.

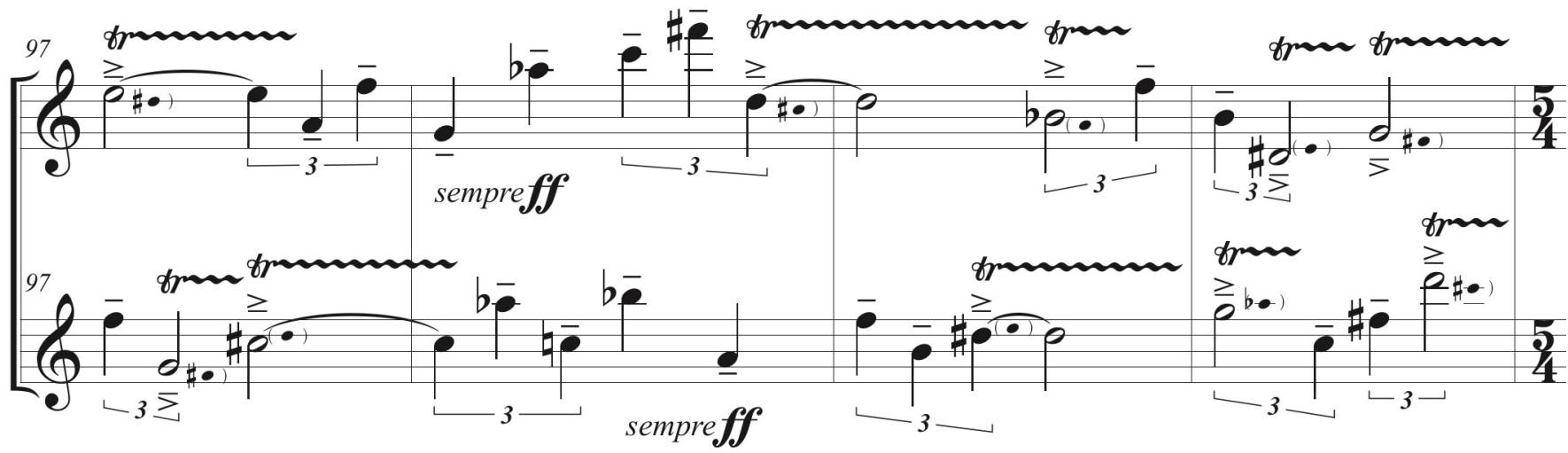

$\mathrm{Ob}$.

Vln.

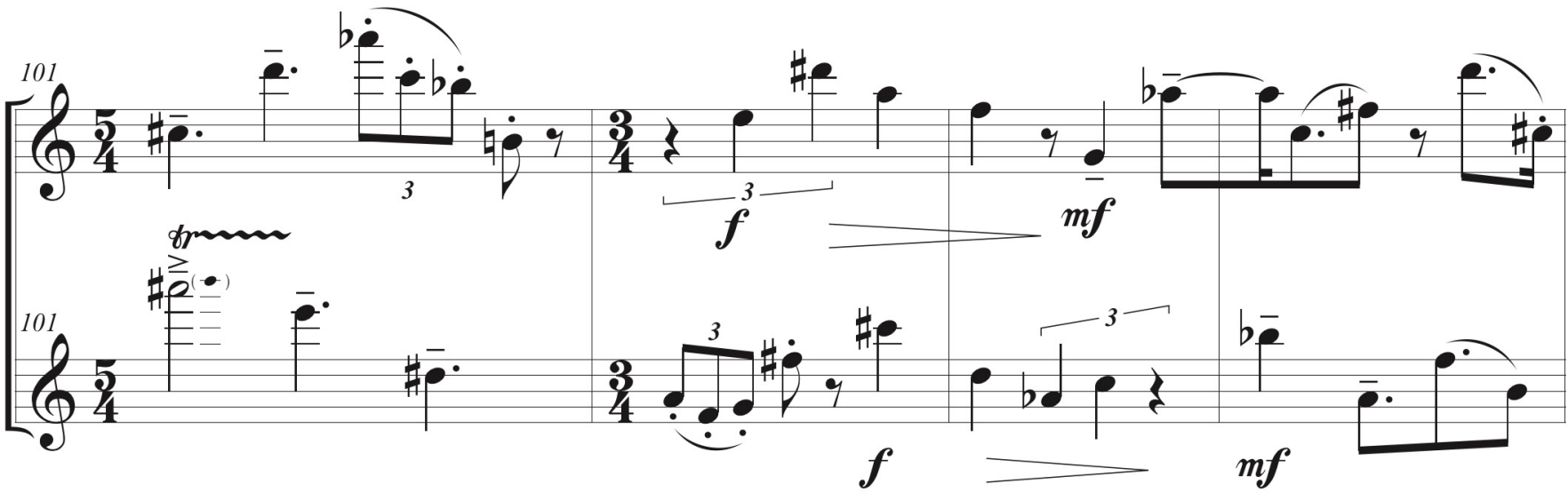

Ob.

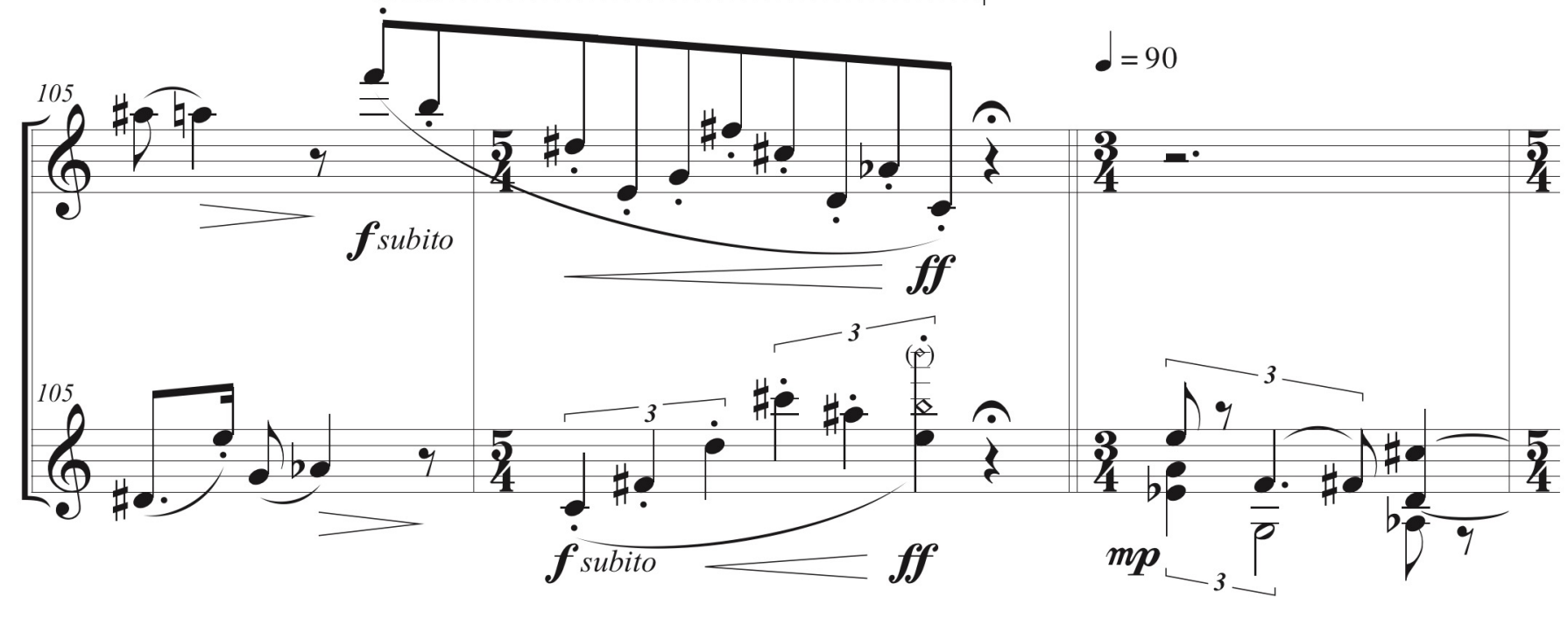

$d=63$

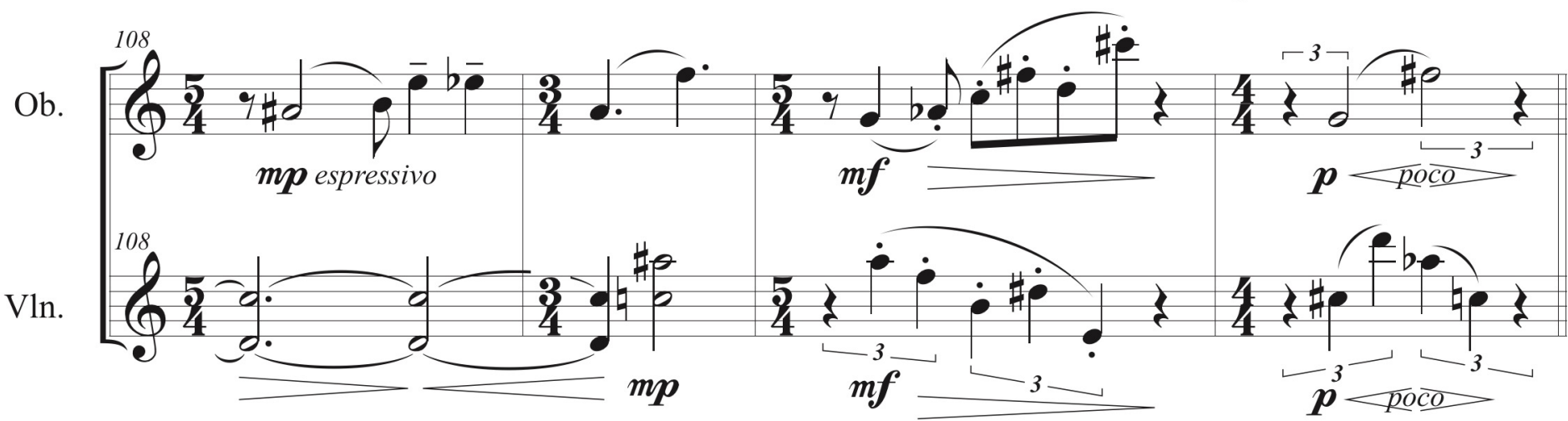




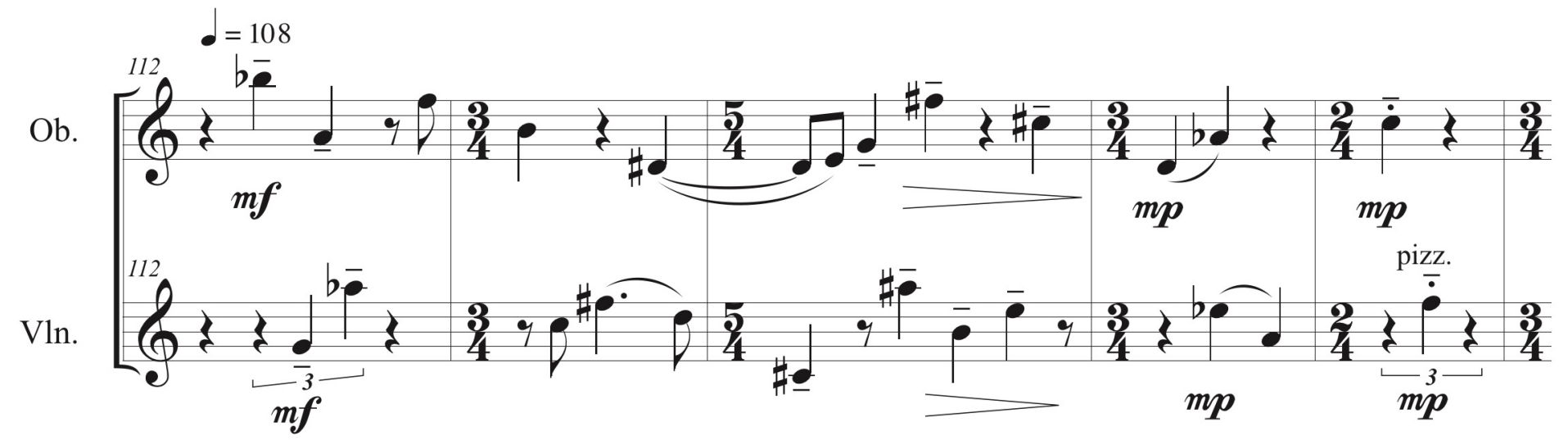
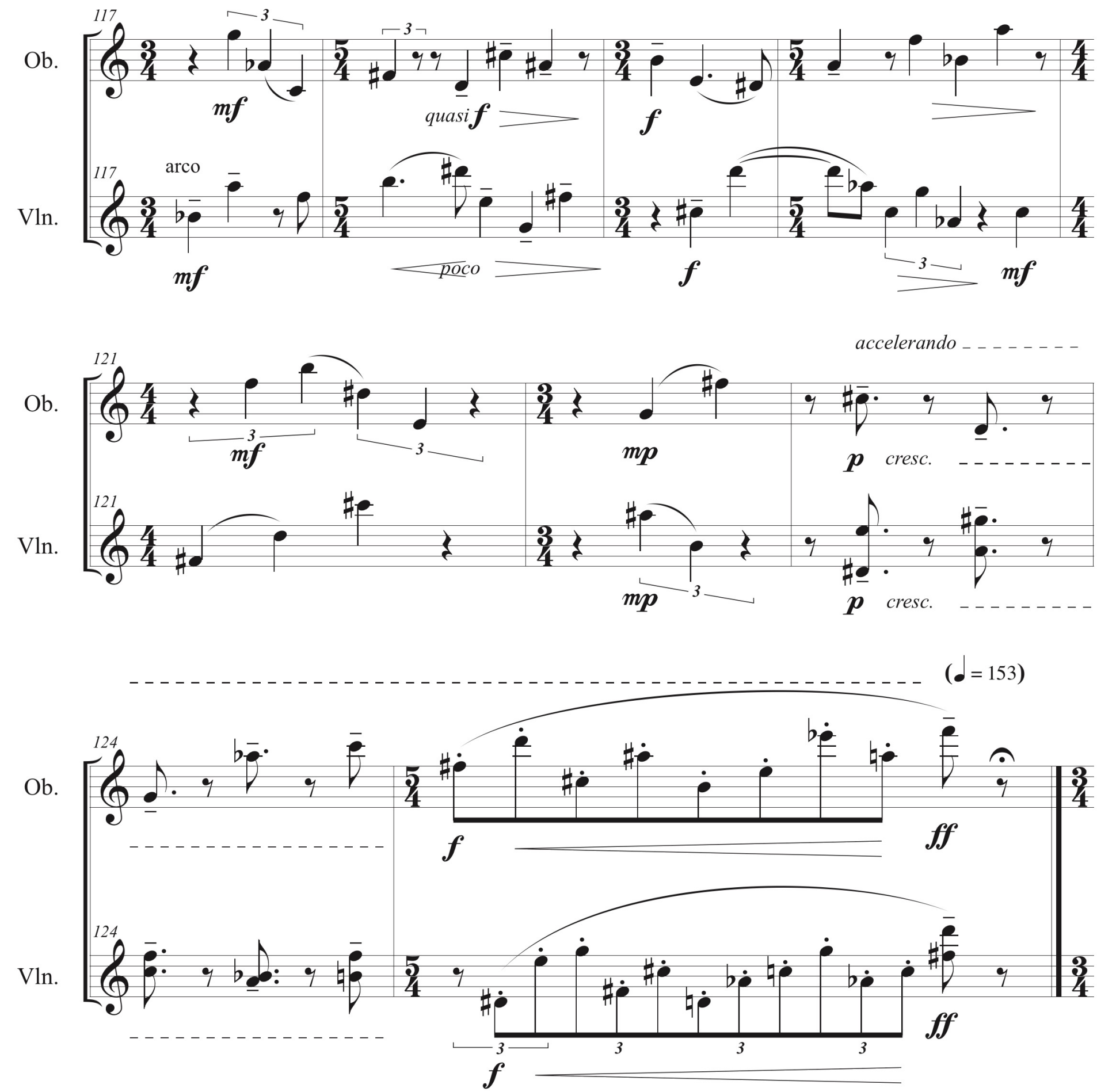

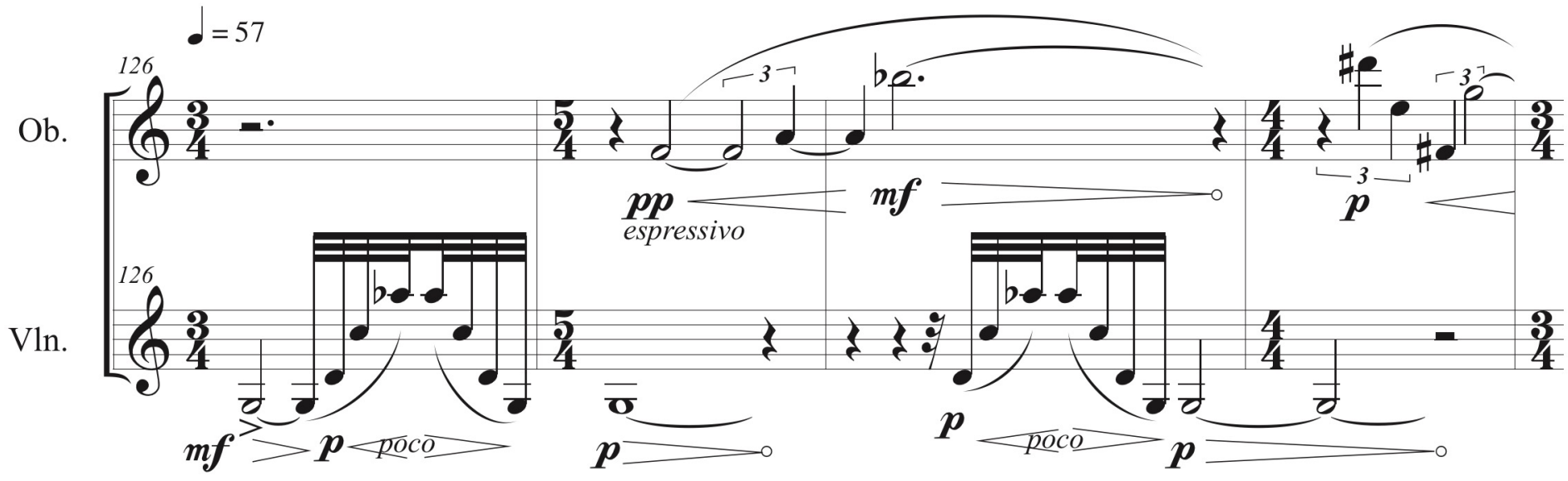

$\mathrm{Ob}$
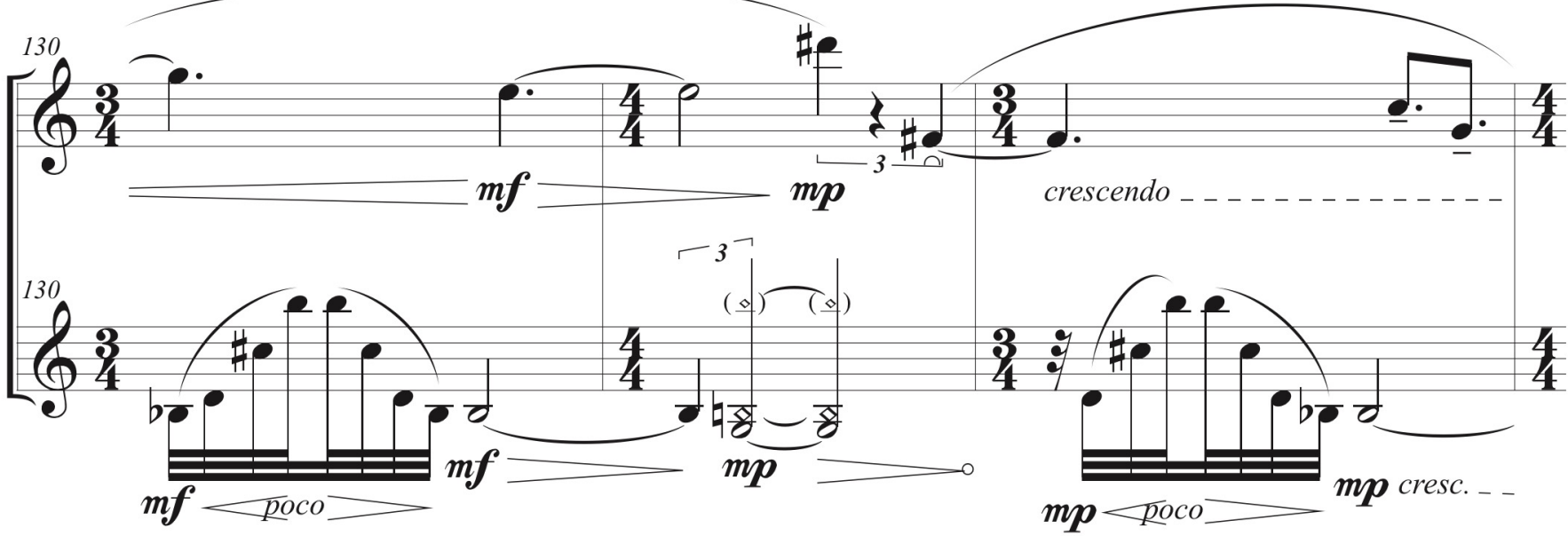

Vln
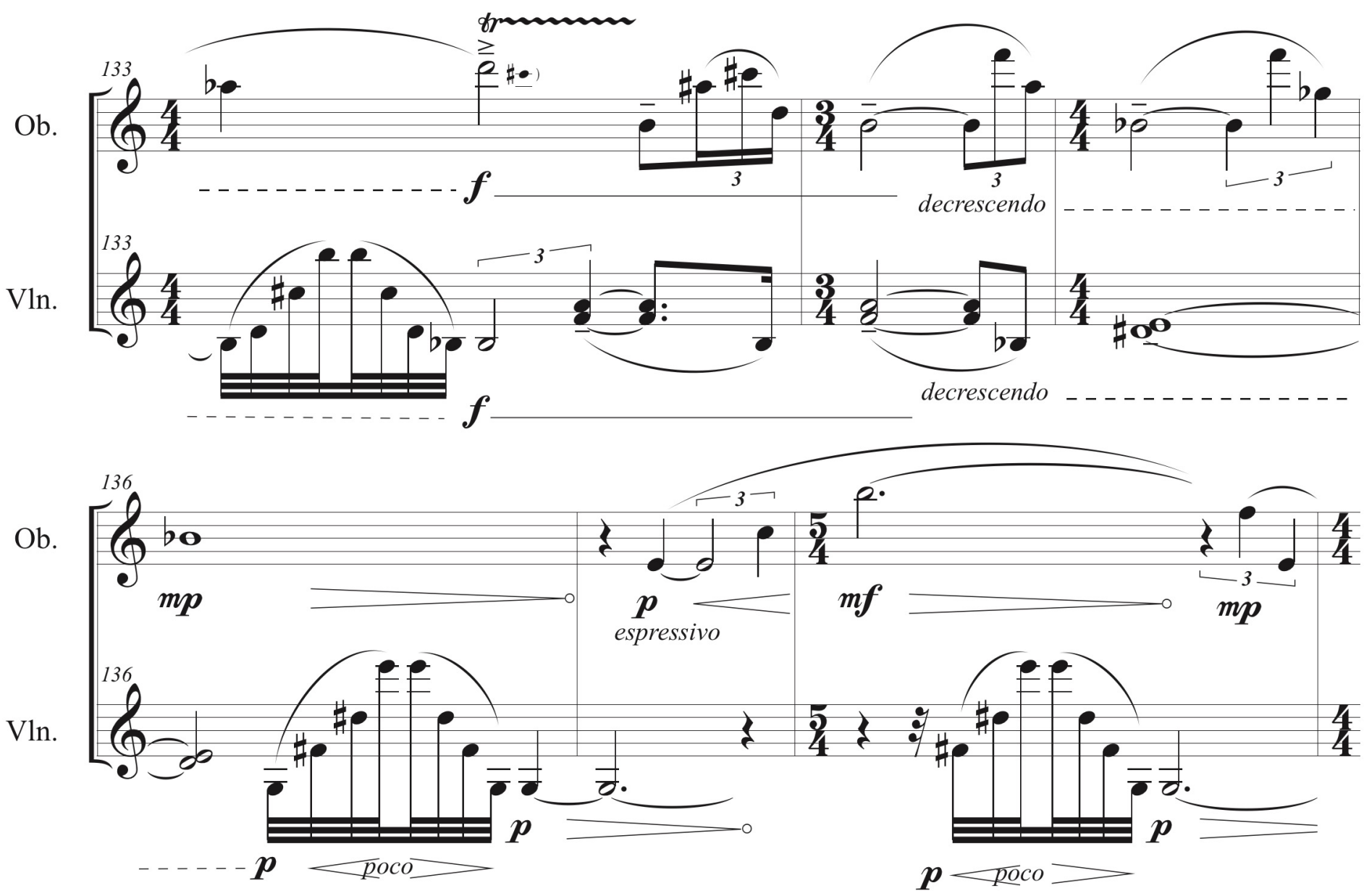
$\mathrm{Ob}$.

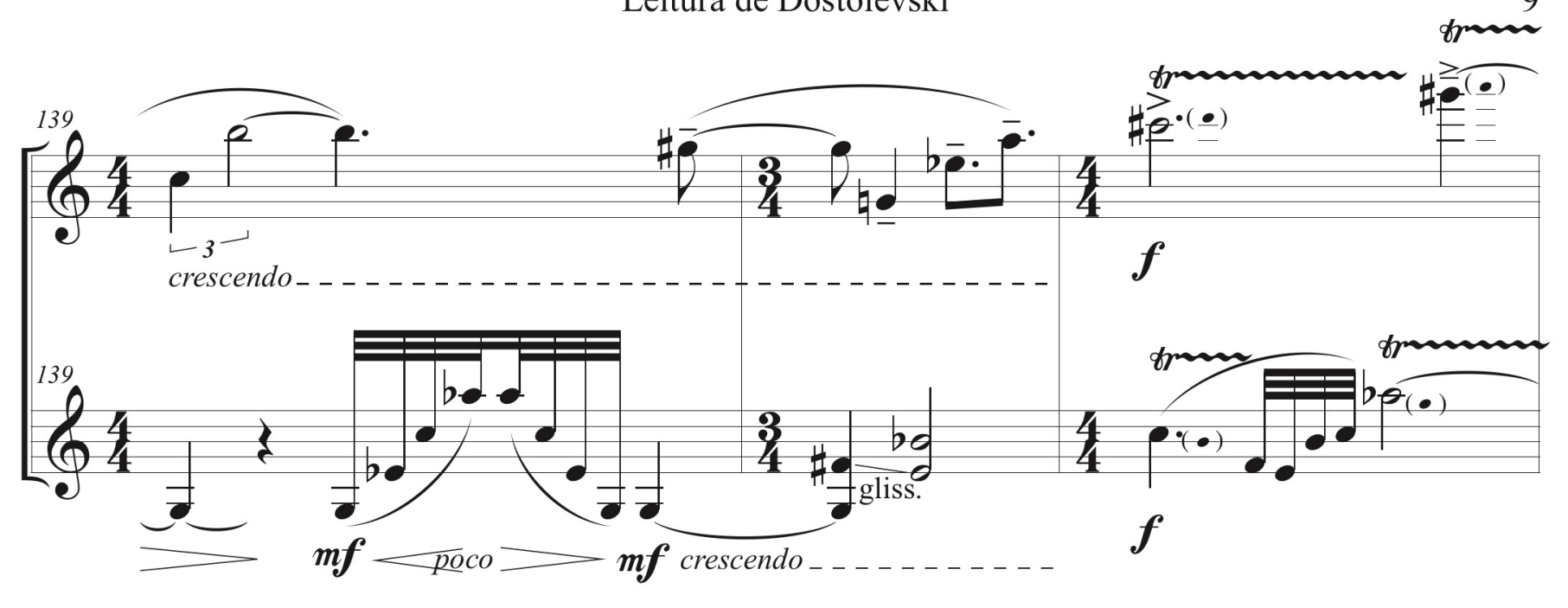

$\mathrm{Ob}$.

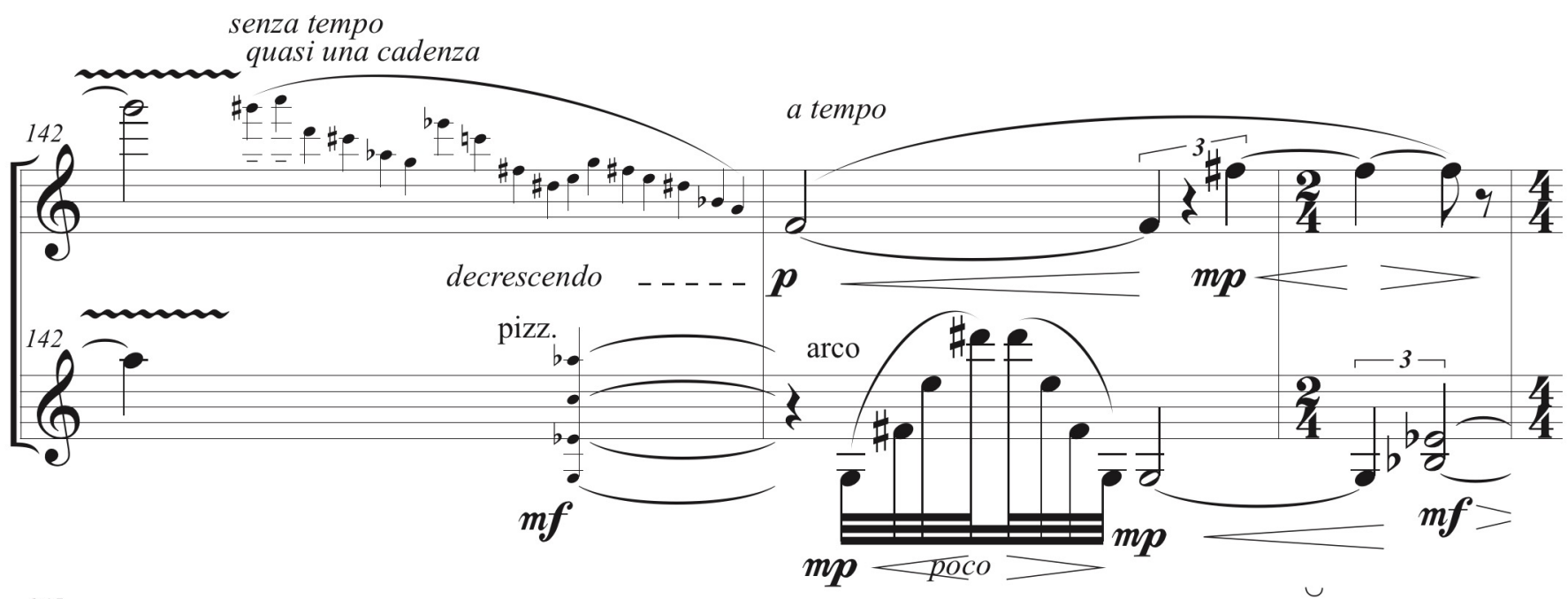

Vln.

$m p-$ росо $=$

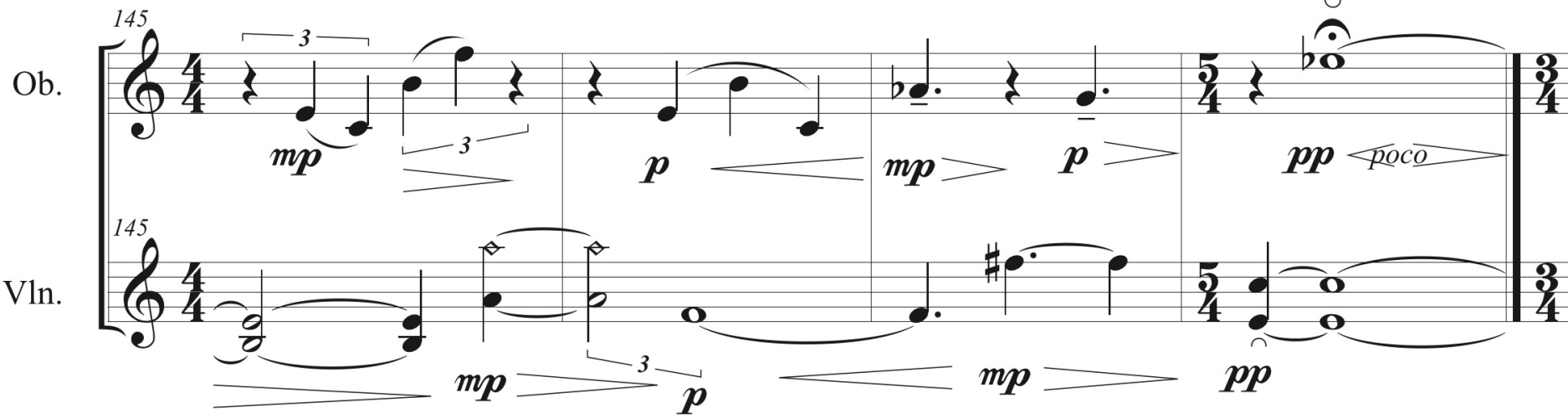

\section{VII}

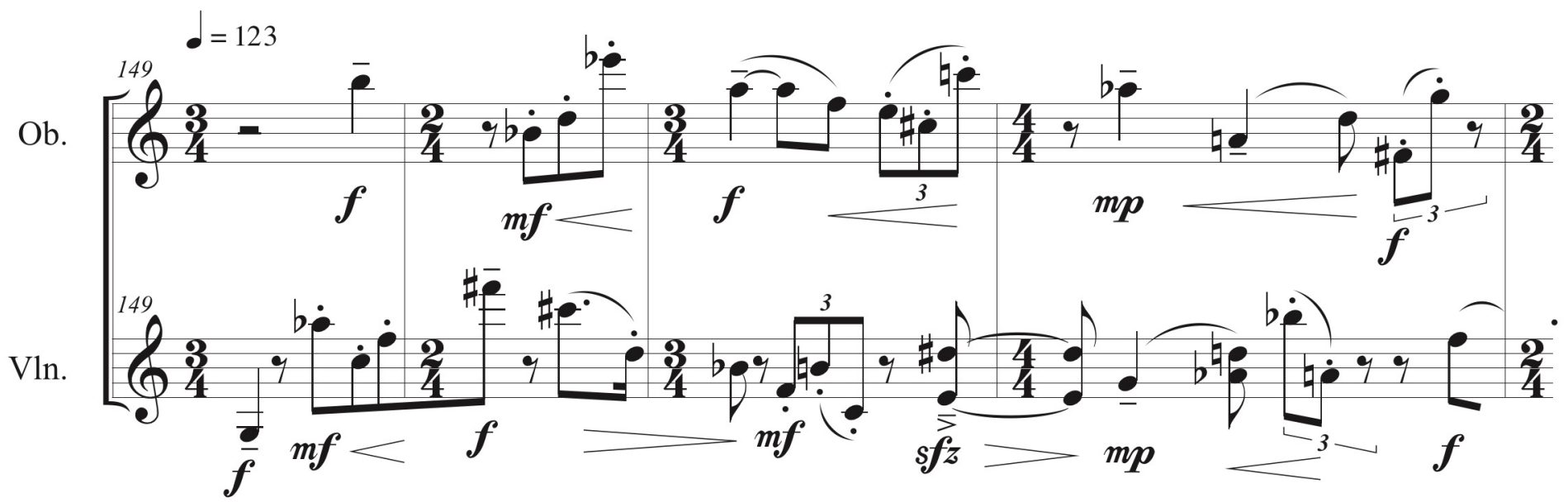


$\mathrm{Ob}$.

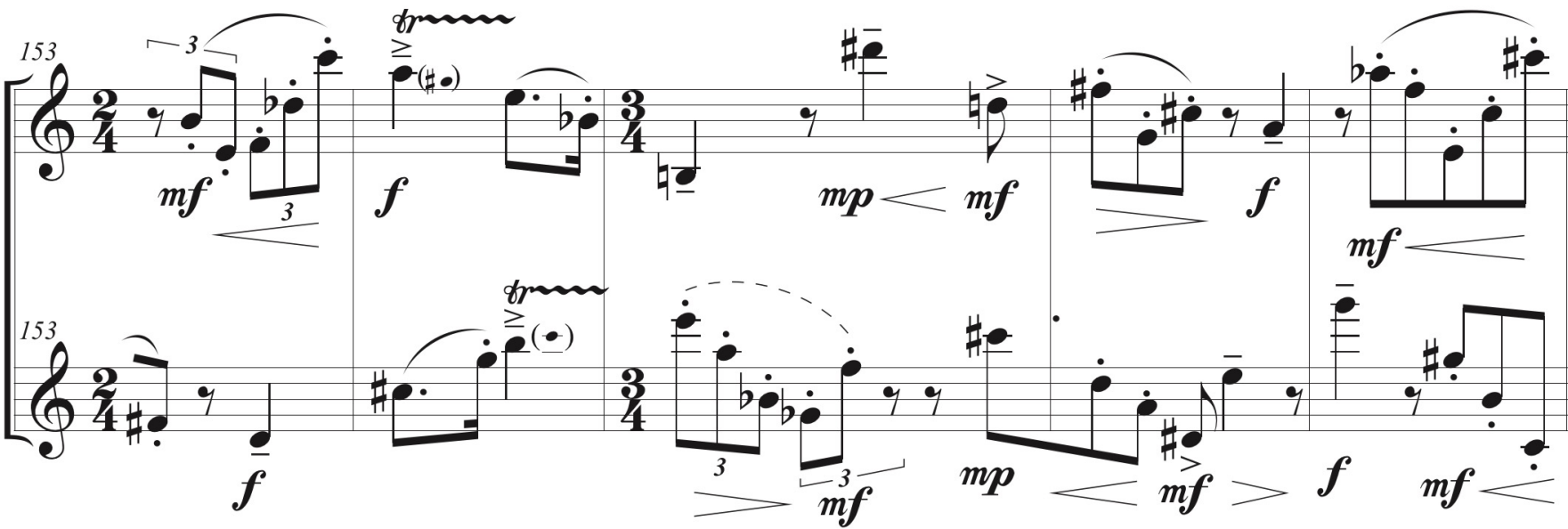

$\mathrm{Ob}$.
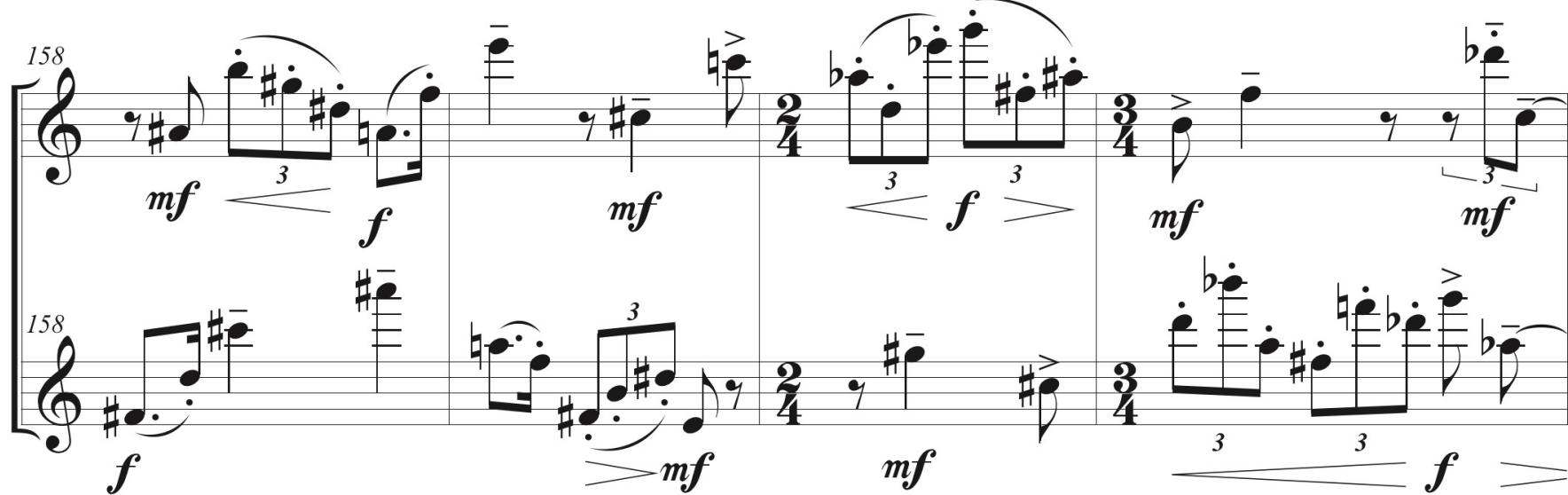

Vln. $\boldsymbol{f}$

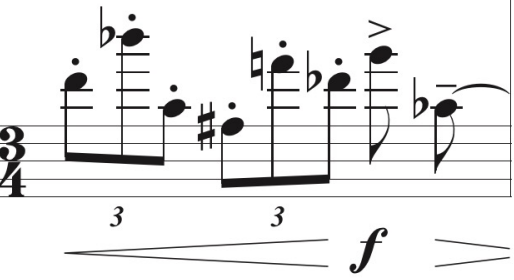

$\mathrm{Ob}$.

Vln.

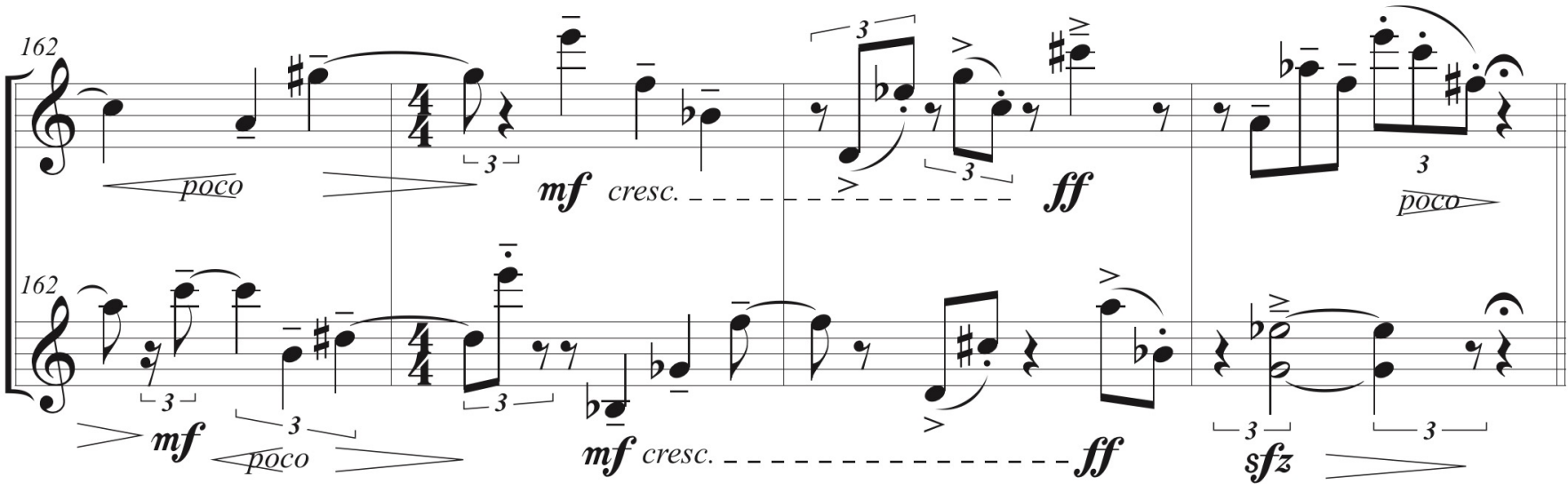

$\mathrm{Ob}$.
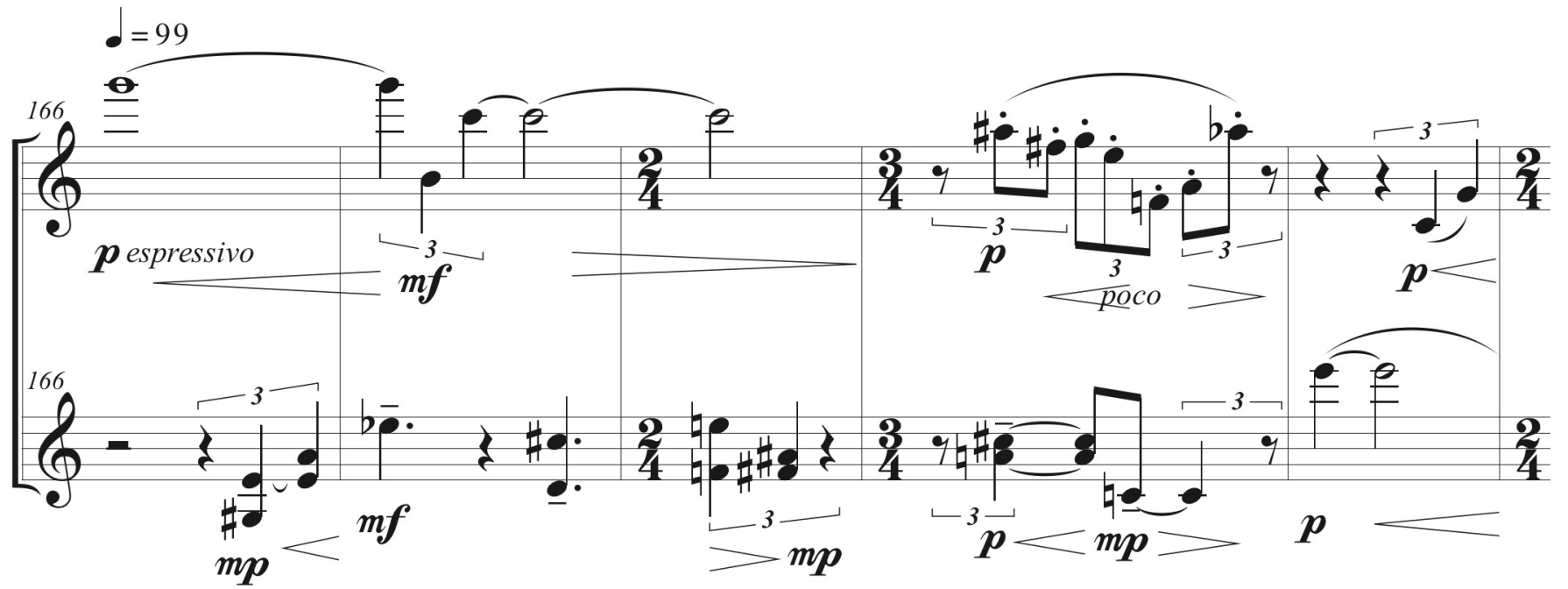

Vln. 
Ob.

Vln.

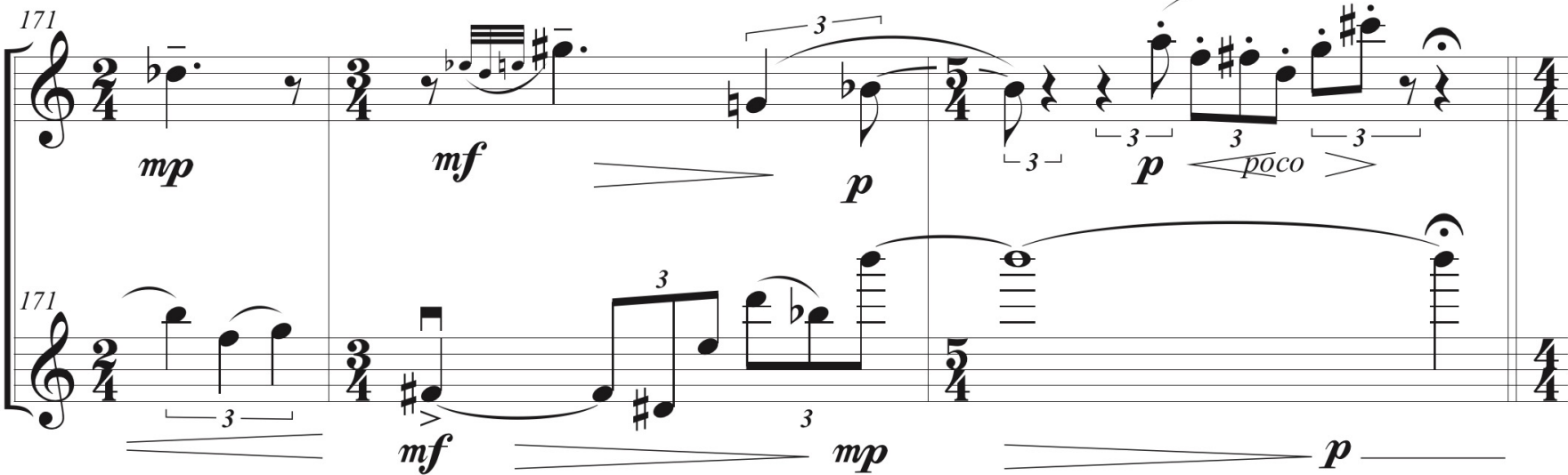

$\mathrm{Ob}$.

- $=123$

Vln.

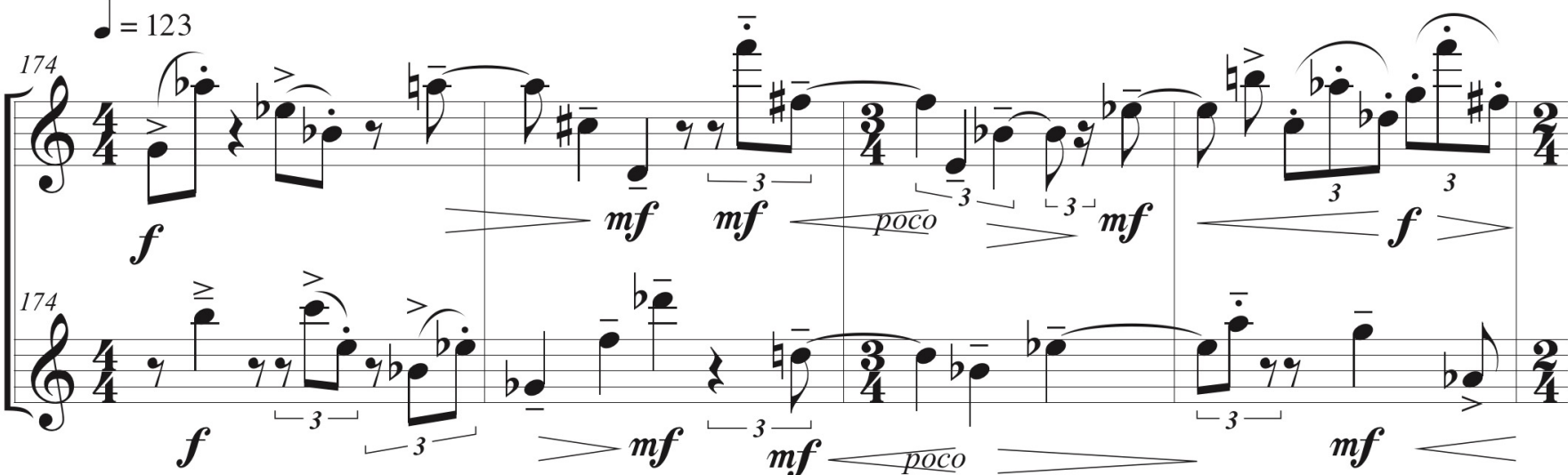

$\mathrm{Ob}$.

Vln.
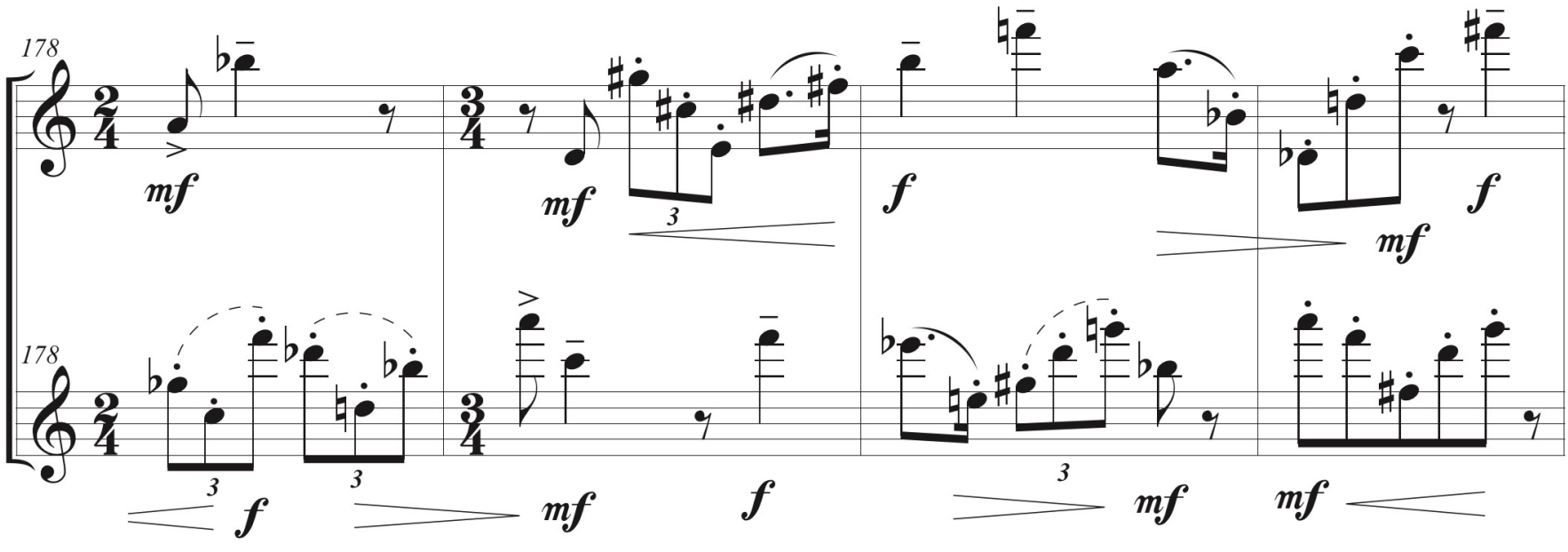

$\mathrm{Ob}$.

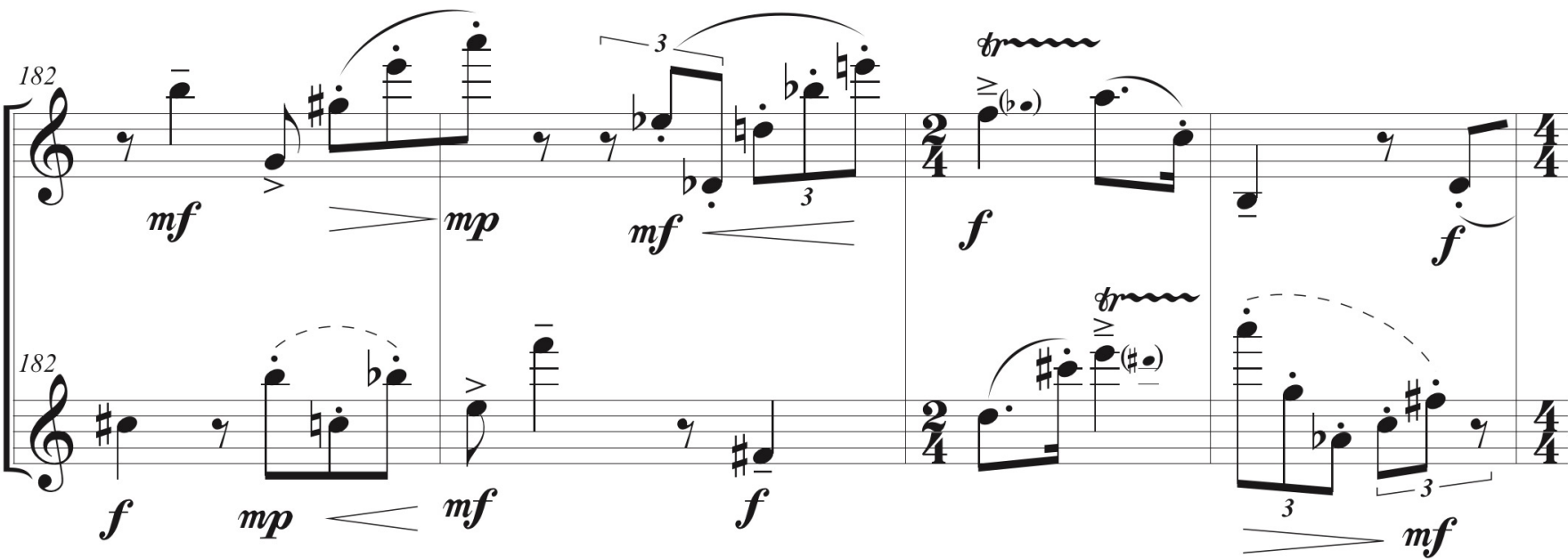


Ob.

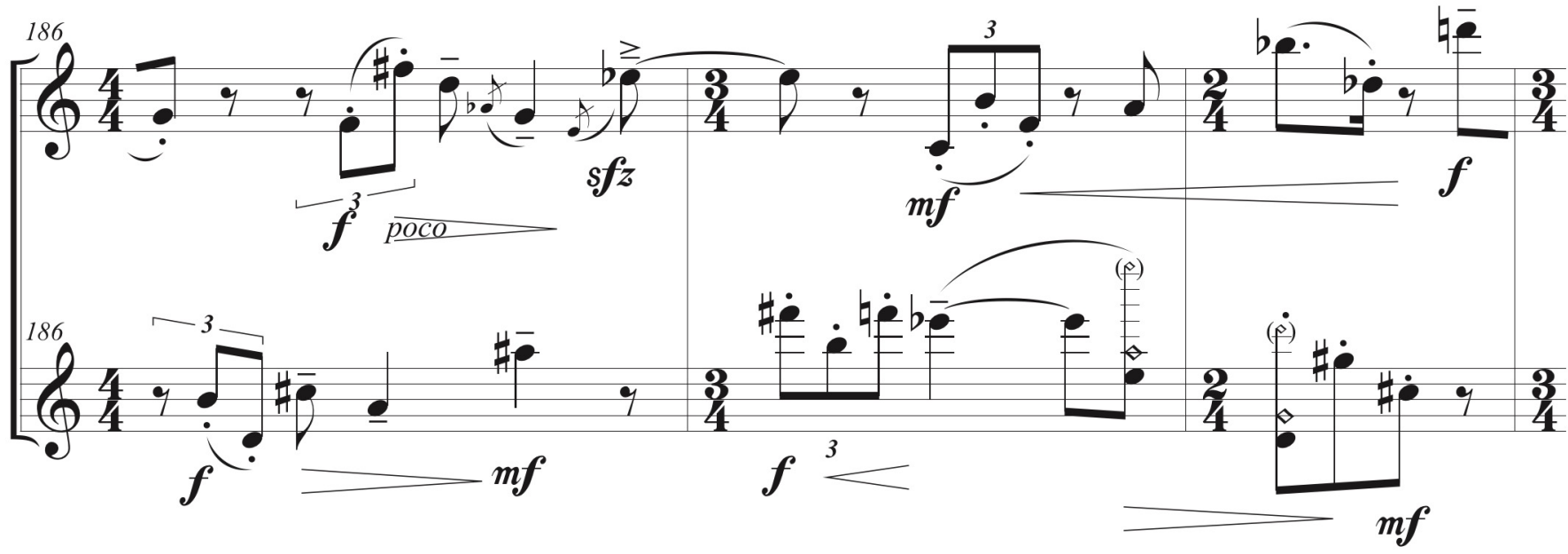

$\mathrm{Ob}$.

Vln.

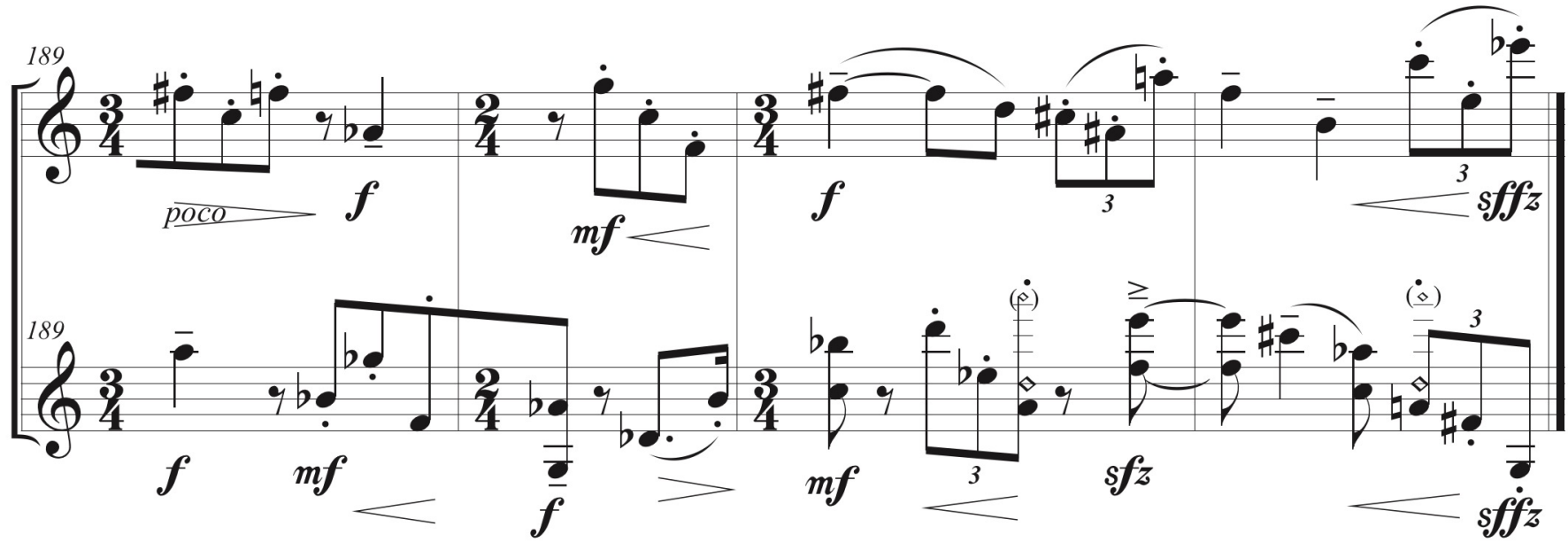

As correntes caíram no chão. ... não conseguia acreditar que não estivessem nos meus tornozelos. ... Liberdade, vida nova, ressuscitado dos mortos ... Que momento glorioso!

Citações extraídas de Recordações da Casa dos Mortos, de Fiódor Dostoiévski, na tradução de Nicolau S. Peticov, Ed. Nova Alexandria, São Paulo, 2015. 